\title{
Important players in carcinogenesis as potential targets in cancer therapy: an update
}

\author{
Justyna Magdalena Hermanowicz ${ }^{1,2}$, Iwona Kwiatkowska ${ }^{1}$ and Dariusz Pawlak ${ }^{1}$ \\ ${ }^{1}$ Department of Pharmacodynamics, Medical University of Bialystok, Mickiewicza, Bialystok, Poland \\ ${ }^{2}$ Department of Clinical Pharmacy, Medical University of Bialystok, Mickiewicza, Bialystok, Poland \\ Correspondence to: Justyna Magdalena Hermanowicz, email: justyna.hermanowicz@umb.edu.pl \\ Keywords: modulators of carcinogenesis; acetylcholine; peroxisome proliferator-activated receptors; aquaporins \\ Received: June 02, $2020 \quad$ Accepted: July 14, $2020 \quad$ Published: August 11, 2020
}

Copyright: Hermanowicz et al. This is an open-access article distributed under the terms of the Creative Commons Attribution License 3.0 (CC BY 3.0), which permits unrestricted use, distribution, and reproduction in any medium, provided the original author and source are credited.

\section{ABSTRACT}

The development of cancer is a problem that has accompanied mankind for years. The growing number of cases, emerging drug resistance, and the need to reduce the serious side effects of pharmacotherapy are forcing scientists to better understand the complex mechanisms responsible for the initiation, promotion, and progression of the disease. This paper discusses the modulation of the particular stages of carcinogenesis by selected physiological factors, including: acetylcholine (ACh), peroxisome proliferator-activated receptors (PPAR), fatty acid-binding proteins (FABPs), Bruton's tyrosine kinase (Btk), aquaporins (AQPs), insulin-like growth factor-2 (IGF-2), and exosomes. Understanding their role may contribute to the development of more effective and safer therapies based on new binding sites.

\section{INTRODUCTION}

The increasing prevalence of various types of cancers is a global phenomenon that has been occurring widely and affecting increasing numbers of people. In 2018, over 18 million new cases were reported and statistics show that every fifth man and every sixth woman is at risk for developing cancer [1]. Carcinogenesis is a multi-stage process that leads to cancer development. It includes three main stages, initiation, promotion and progression, and each is characterized by different processes. During the promotion stage the genetic material of cells is damaged and if not detected by repair systems before the next division, the change is transferred to newly formed cells. Under the control of growth factors, initiated cells may move on to the second stage of cancer formation-promotion. During that stage, mutated cells undergo multiple divisions, their growth is uninhibited as they become insensitive to apoptotic signals. As a result, the tumor increases its mass, but the cells remain within one organ. The formation of metastases occurs in the next phase-progression. Metalloproteinases secreted by tumor cells destroy the extracellular matrix. This allows them to enter the bloodstream and reach a new organ, at a considerable distance from the primary lesion, with the stream of flowing blood. The key step for the survival of migrating cells is adhesion to the attacked organ and the formation of new blood vessels, thanks to which they will receive the components necessary for development. Angiogenesis, the formation of new blood vessels, is the last element of carcinogenesis and is enhanced by tumor cell derived factors, metabolic changes, and a decrease in available oxygen. Each of these processes is controlled by different signal pathways via proteins that naturally occur in the body (Figure 1). Dysregulation of their expression, and thus activity, both to an excessive and insufficient degree, ensures the continuity of carcinogenesis and increases the chances cancer cells survive in a host organism. Understanding the role of individual substances and components of the body in the subsequent stages of neoplastic transformation provides a more complete picture of cancer pathogenesis. This allows to develop new recommendations, to improve the quality and safety of pharmacotherapy, which has a direct effect on an improvement in the cancer patients' quality of life. It also provides the basis for research aimed at developing new compounds that are effective weapons in the fight against cancer. Therefore, there is no doubt that any actions that bring scientists closer to solving the problem of insufficient cancer therapy are sensible and much needed. The purpose of this paper was to discuss the role of selected physiological factors in the various stages of neoplastic transformation. 


\section{Crucial mechanisms involved in carcinogenesis}

The carcinogenic process is regulated by many molecular and cellular mechanisms. The diversity of signaling pathways exploited during cancer initiation, promotion and progression is immense. Many of them are common in different cancer types, but there are also clearly unique molecular and cellular signaling signatures specific for particular cancers [2]. Pathways such as Akt-PI3K, Ras/MAPK/ERK, Wnt/B-catenin, JAK-STAT occupy crucial roles in the regulation of cell proliferation, apoptosis, differentiation, angiogenesis, cell migration and invasion, immunological activities, and inflammation.

PI3K, phosphatidylinositol 3-kinase, is a family of enzymes that after activation by growth factors, cytokines, and hormones are involved in the conversion of PIP2 (phosphatidylinositol-4,5-bisphosphate) into PIP3 (phosphatidylinositol $(3,4,5)$-trisphosphate) [3]. The latter in turn takes part in recruiting Akt into the cell membrane, where it is phosphorylated and activates other agents, such as mTOR, NF-kB, Wnt or inhibits factors like Bad, p27 to enhance carcinogenesis. Dysregulation of this pathway occurs in endometrial [4], bladder [5] or gastric cancers [6]. The aforementioned PIP2 can be also transformed by phospholipase $\mathrm{C}$ into DAG and IP3, which then activate protein kinase $\mathrm{C}$ (PKC) [6]. One of the PKC substrates is Raf kinase, which is an element of the Ras/MAPK/ ERK pathway, which is involved in the pathogenesis of ovary cancer [7] or non-small cell lung cancer [8]. Ras proteins activate Raf, which then phosphorylates kinases MEK1/2. Its final substrate is kinase ERK1/2, which after transportation into the nuclei regulates transcription factors, essential for DNA synthesis and cell cycle progression. They condition cell growth, proliferation and viability [9]. Because of that, targeting those two cascades as an anticancer therapy seems to be beneficial. However, it is important to notice that the existing crosstalk between both of the pathways can impede treatment, and inhibition of one can strengthen the activity of the other. Another component that is also connected with the MAPK family

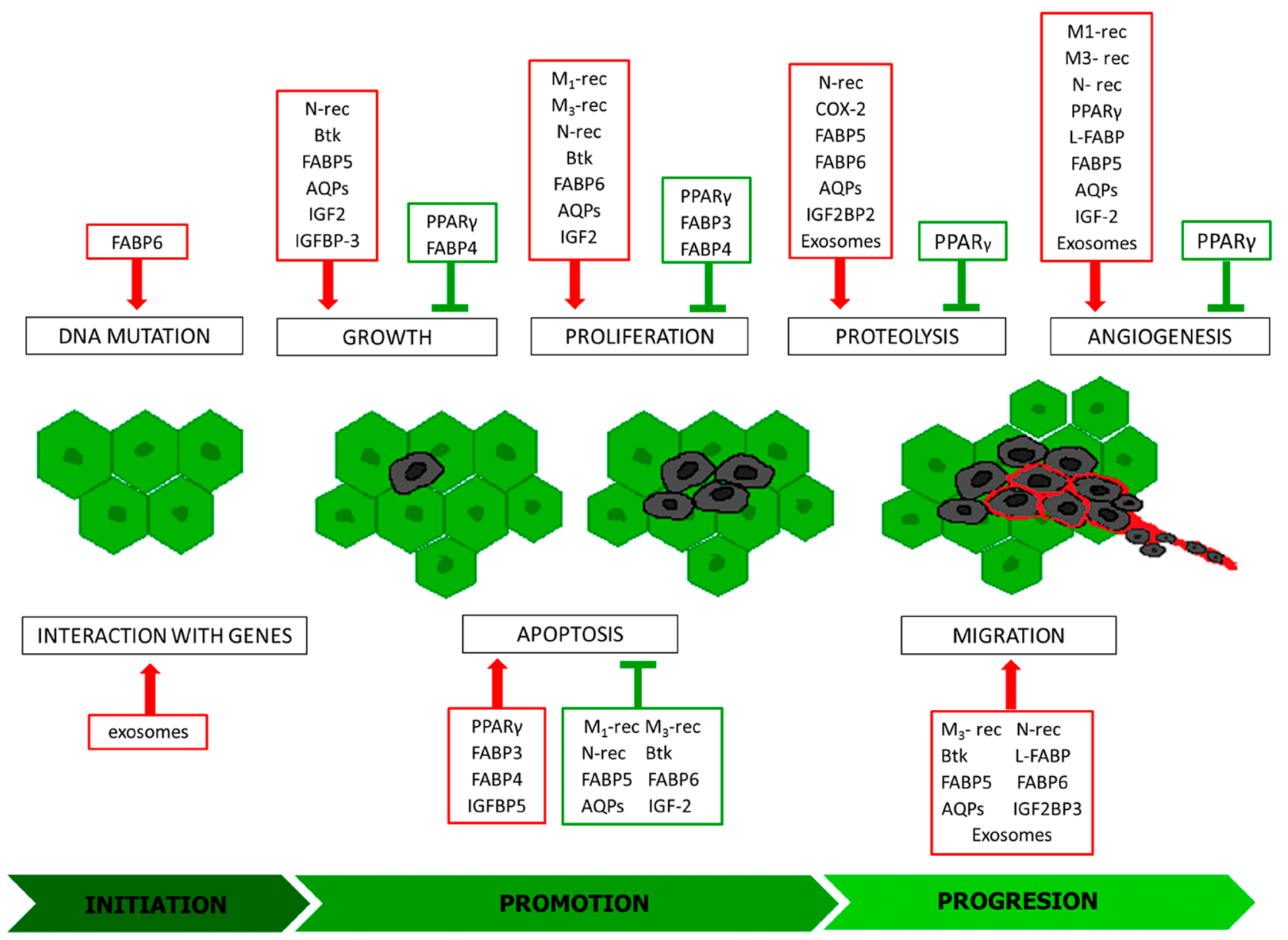

Figure 1: Modulators of individual stages of carcinogenesis. Inducers: red frames, inhibitors green frames; M1-rec: muscarinic receptor 1; M3-rec: muscarinic receptor 3; N-rec: nicotinic acetylcholine receptor; COX-2: cyclooxygenase-2; PPAR $\gamma$ : peroxisome proliferator-activated receptors gamma; Btk: Bruton's tyrosine kinase; FABP 3-6: fatty acid-binding protein 3-6; L-FABP: L-type fatty acidbinding protein; AQPs: aquaporins; IGF2: insulin-like growth factor 2; IGFBP-3: insulin-like growth factor binding protein 3; IGFBP5: Insulin Like Growth Factor Binding Protein 5; IGF2BP2: Insulin Like Growth Factor-2 mRNA Binding Protein-2; IGF2BP3: Insulin Like Growth Factor-2 mRNA Binding Protein- 3. 
is a signaling pathway conducted by p38MAPKs. This subfamily contains four kinases, which are activated mainly by inflammatory cytokines and stress factors. p38MAPKs control many aspects of cell physiology such as cell cycle regulation, differentiation or skeleton remodelling. Additional p38MPAKs can act as tumor promotors by enhancing metalloproteinase and VEGF expression [10].

Wnt/ $\beta$-catenin signaling plays essential roles in caricinogenesis. Activation of canonical Wnt signaling results in the inhibition of GSK-3 $\beta$ kinase, dissociation of $\beta$-catenin proteins and its transfer to the nucleus where it regulates multiple downstream genes like c-Myc and cyclin D [11]. This axis was found to be associated with several oncogenic events including tumor cell proliferation, migration, epithelial-mesenchymal transition and invasion. An abnormally active Wnt/B-catenin pathway is observed, among others in gastric [12], colon [13], breast [14], or adrenocortical cancer [15]. Another signaling pathway involved in the pathogenesis of many cancer types is that induced by the Jak kinases family. It includes four kinases, which after activation impact of the STAT molecules causing their translocation into the nuclei [16]. STAT, a family that gathers seven forms of proteins, is associated with cancer cell development, progression, metastasis, survival and resistance to treatment [17]. STAT3 and STAT5 factors seem to be the most important agents in light of cancer progression. They have an impact on p53 protein, which leads to a disruption in cycle control and apoptosis and induces cell proliferation by the increased c-Myc and cyclin D expression. By the induction of VEGF gene expression, they take part in enhanced angiogenesis and induction of genes such as survivin, Bcl-2, Bcl-XL conditioning overall survival of the tumor cells. Moreover, pSTAT3 acts to negatively regulate neutrophils, NK cells, effector $\mathrm{T}$ cells and dendritic cells, while positively regulating populations of MDSCs (myeloid-derived suppressor cells) and regulatory $\mathrm{T}$ cell leads to a highly immunosuppressive TME (tumor microenvironment) [18].

Multiple endogenous factors are involved in carcinogenesis, which affects particular stages of carcinogenesis in various mechanisms. Some of them interact directly with the DNA, intracellular signalling molecules, others by specific cellular receptors. Among them are well known growth factors (EGF, TGF- $\alpha$ and TGF- $\beta$, FGF) or reactive endogenously generated oxygen molecules as well as less often described agents like ACh, PPAR, FABPs, Btk, AQPs, IGF-2, or exosomes. The latter have only recently gained in importance and are more widely studied and discussed therefore are considered in this article.

\section{Aacetylcholine (Ach) and its receptors}

One of the factors involved in the carcinogenesis process is acetylcholine and its receptors, both muscarinic and nicotinic. Their expression has been demonstrated in numerous types of cancer cells [19-21]. It has also been proven that these cells contain acetylcholinesterase (AChE), an enzyme that enables cells to produce ACh in the absence of agonists from the external environment. Cancer cells also have the ability to produce autoantibodies that stimulate one of the muscarinic receptor subtypes, M3. These facts prompted more extensive research to explain the exact role of $\mathrm{ACh}$ and its receptors in the carcinogenesis process (Figure 2). Muscarinic receptors can be divided into five subtypes, each of which is involved in tumor development through a different mechanism. The role of muscarinic M3 receptor is the most widely described subtype. It is involved in the pathogenesis of lung, colon, gastric, and breast cancer. In the course of colon cancer, it has been observed that stimulation of the M3 receptor causes phosphorylation of the Akt and ERK1/2 kinases, which are factors that through the ability to regulate the activity of pro- and anti-apoptotic proteins affect the intensification of cell proliferation, survival and motility. In addition, co-expression of the M3 receptor and endothelial growth factor receptor (EGFR) as well as EGFR transactivation after M3 receptor stimulation has been demonstrated $[22,23]$. Moreover, the administration of EGFR inhibitors inhibits acetylcholine-induced ERK1/2 kinase phosphorylation, which is reflected in a significant decrease in colon cancer cell proliferation. This indicates that acetylcholine is involved in the formation of colon cancer, but for its full action it is necessary to activate the EGFR receptor. Thus indicating that enriching colon cancer treatment with EGFR inhibitors may improve patient outcomes. Acetylcholine is also involved in the formation of vascular-like structures in the vicinity of a developing tumor, guaranteeing the supply of essential nutrients to the proliferating cancer cells. This is called vascular mimicry. The basis of this process is the acetylcholine-dependent regulation of metastasis-associated in colon cancer-1 (MACC1) oncogene expression via the M3R/AMPK/MACC1 signaling pathway [24]. High activity of this oncogene is associated with an increase in cell invasiveness, intensified epithelial-mesenchymal transition, more frequent metastases, and hence worse treatment prognosis [25-27]. The first subtype of the M receptor (M1) is also involved in the tumor development process. It activates the hedgehog pathway $[19,28]$ whose physiological role is to regulate the transcription factors affecting the oncogenic activity of Gli (zinc finger transcription factors) $[29,30]$. Excessive stimulation causes acceleration of carcinogenesis, intensification of proliferation, growth and survival of cancer cells as well as angiogenesis by affecting the expression of genes such as cyclin D, antiapoptotic Bcl-2, or VEGF. Furthermore, stimulation of this pathway promotes the creation of a microenvironment conducive to tumor growth through increased expression of extracellular matrix components [31]. Nicotinic 
acetylcholine receptors are part of the ligand-gated ion channels, and are created from two types of subunits, $\alpha$ and $\beta$. Receptors that contain an alpha7 or alpha9 subunit in their structure are characterized by a high degree of permeability to calcium ions, thanks to which they are involved in the course of numerous processes based on signaling involving secondary messengers. Thus, after activating $\mathrm{N}$ receptors, $\mathrm{Ca}^{2+}$ inflows into the cell, causing the secretion of growth factors exerting paracrine action on neighboring cells. Simultaneously, apoptosis is inhibited enabling further proliferation. Studies conducted on a lung cancer cell line after exposure to cigarette smoke have shown that nicotine and nitrosamines, which have a higher affinity for nicotinic acetylcholine receptors (nAChRs) than nicotine, bind to the alpha7 receptors activating the Ras/ERK/MAPK and the JAK2/STAT3/PI3K signaling pathways $[32,33]$. The effect of this interaction is increased proliferation and migration of cancer cells, and thus facilitated metastasis creation. Moreover, by affecting B-adrenergic receptors, nicotine intensifies COX-2 expression, which through the p38 MAPK and the JNK pathways leads to an increase in VEGF production, a highly pro-angiogenic factor. In addition, the high activity of cyclooxygenase affects the inactivation of the PTEN protein [34, 35], whose biological role is silencing PI3K/Akt pathway signaling. This leads to cellular signal transition and induces effects that contribute to the enhanced growth and proliferation of cancer cells as well as inhibits the process of their death. Under the influence of the Akt kinase, proapoptotic transcription factors are inactivated, including kinase-9, mTOR kinase intensifying cell proliferation is activated, and VEGF is activated. This indicates the involvement of this pathway in processes that facilitate cancer cell survival. Another mechanism contributing to cancer development in which cyclooxygenase 2 is involved is the complex process involving the COX-2/PGE2/EP4 axis, as a result of which metalloproteinase 9 expression is stimulated [36-38]. MMP-9 causes proteolytic activation of TGF- $\beta$, which begins the induction of epithelial-mesenchymal transformation (EMT). During this transition, the cells acquire features that increase their invasiveness. This leads to epithelial cell phenotype changes, the connections between adjacent cells and between cells and the basement

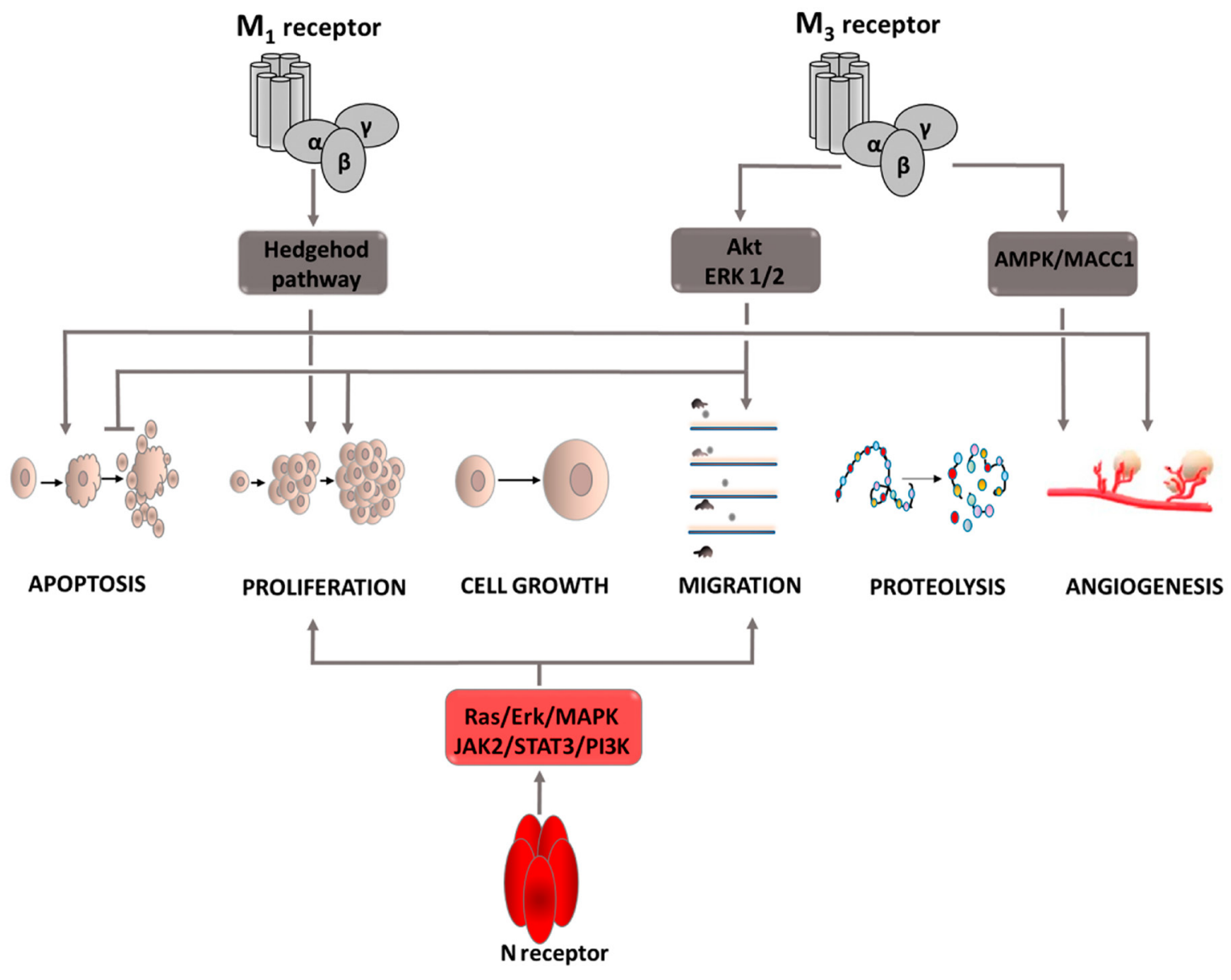

Figure 2: Carcinogenic effect of acetylcholine (Ach). Intracellular signaling pathways activated by ACh via M1 and M3 receptors. Induction of process is illustrated by arrows, inhibition by horizontal lines. M1: muscarinic receptor 1; M3: muscarinic receptor 3; N receptor: nicotinic acetylcholine receptor; Akt: protein kinase B; ERK: extracellular signal-regulated kinase; JAK2: Janus kinase 2; PI3K: phosphoinositide 3-kinase; STAT3: signal transducer and activator of transcription proteins; MAPK: mitogen-activated protein kinase. 
membrane are loosened, the cytoskeleton is rearranged, cells lose contact inhibition, thus causing excessive proliferation. Furthermore, the microenvironment of the growing tumor also changes, promoting features that facilitate the movement of the cancer cells from the primary focus to other regions of the body. Through the EMT process, cells acquire greater migration capacity, and thus their invasiveness increases. In this cellular process, MMP-9 also modulates the activity of integrins and other molecules that ensure cell adhesion [39], and secrete soluble factors into the bloodstream that facilitate the implantation of migrating cells in organs distal to the primary tumor focus [40]. Thanks to these processes, COX-2 enables the formation of cancer metastases.

\section{PPAR: peroxisome proliferator-activated receptors}

The family of peroxisome proliferator-activated receptors (PPARs) includes 3 isoforms of these proteins that function as transcription factors. Each type of steroid receptor differs in its location and affinity for ligands [41]. The best known is the function of the PPAR $\gamma$ form. Agonists of this receptor are a therapeutic option in the treatment of patients with diabetes. Current research provides evidence that stimulation of PPAR $\gamma$ receptors inhibits cell proliferation, vessel formation, and induces apoptosis (Figure 3) [42, 43]. These properties make PPAR $\gamma$ agonists attractive candidates for anti-cancer drugs. To achieve full transcriptional activity, heterodimerization of PPAR $\gamma$ with the retinoid $\mathrm{X}$ receptor is necessary $[44,45]$. This interaction enables the promoter to bind with the target gene and regulate its expression. An example of a gene against which PPAR $\gamma$ acts as a repressor is the vascular endothelial growth factor (VEGF) gene [46]. Thus, angiogenesis is inhibited, and this mechanism has been demonstrated in studies on human hepatocellular carcinoma (HCC) cells [47]. For this cancer, PPAR $\gamma$ is also involved in inhibiting cell growth and attenuating cell migration and invasiveness. By upregulating KLF-4 (Krüppel-like factor 4) expression and inhibiting cyclin D1 expression, the cell cycle is inhibited. Furthermore, PPAR $\gamma$ negatively affects the expression of transcription factor STAT3, thereby inhibiting proliferation, survival and metastasis. Lowering STAT3 levels also negatively affects the angiogenesis process (by inhibiting VEGF) depriving cancer cells of nutrients. PPAR $\gamma$ activation in HHC cells also impairs their metastatic ability [48]. This is associated with the inhibition of the expression of metalloproteinases, MMP9 and MMP13, the increased expression of their inhibitor and E-cadherin, a protein conditioning cell adhesion. In addition, PPAR $\gamma$ increases plasminogen activator inhibitor expression, thus inhibiting the breakdown of the extracellular matrix and basement membrane proteins, which also reduces cancer cell invasiveness. PPAR $\gamma$ has also been shown to inhibit esophageal cancer [49]. The mechanism responsible for suppressing this tumor is MAPK signaling pathway inhibition. This process requires TLR4 (Toll-like receptor 4) inhibition, which allows PPAR $\gamma$ agonists to be administered. TLR4 is a pro-carcinogenic protein and affects, among others, changes in the tumor microenvironment and the severity of angiogenesis. Therefore, in addition to the indirect effect on the MAPK cascade, its inhibition is an important element of tumor suppression. Studies on esophageal cancer cells indicate that PPAR $\gamma$ stimulation leads to a decrease in PCNA (proliferating cell nuclear antigen factor) expression, which indicates inhibition of DNA replication [49]. In addition, PPAR $\gamma$ activation intensifies the process of apoptosis, as evidenced by an increase in the expression of the active form of caspase 3 and the Bax gene, and a decrease in Bcl-2 expression. In nonsmall-cell lung cancer, PPAR $\gamma$ stimulation inhibits the neoplastic process by regulating PTEN protein expression [50]. This protein is a tumor suppressor and its activation causes the dephosphorylation and inactivation of the PIP3 second messenger. As a result, Akt kinase activity is inhibited leading to a decrease in NF-kB expression. Due to PPAR $\gamma$ stimulation by eicosapentaenoic acid (EPA), a relationship is sought between PPAR $\gamma$ and COX-2 activity that uses EPA as a substrate for prostanoid production. The combination of PPAR $\gamma$ agonists with COX-2 inhibitors has demonstrated a synergistic tumor-suppressing effect in studies on non-small-cell lung cancer. Researchers indicate significantly reduced thromboxane TX-A2 synthesis using combination therapy compared with monotherapy as the main mechanism of this phenomenon [51]. A decrease in its concentration limits signaling in four pathways, ERK, p38 MAPK, JAK, and $\beta$-catenin, limiting tumor growth [52]. Furthermore, it affects the arrest of the cell cycle in the $\mathrm{G} 2 / \mathrm{M}$ phase, preventing further cell division and contributing to the reduction of the expression of survivin, an anti-apoptotic protein [53]. The described mechanisms affect the induction of the apoptosis process and inhibit cell cycle progression, which limits cancer development. The above examples indicate that peroxisome proliferatoractivated receptors play a significant role in inhibiting the development of various types of cancer, which is why agonist compounds can be considered potential anti-cancer drugs. However, further comprehensive and extensive research is needed to identify potential applications and treatment regimens.

\section{Btk: Bruton's tyrosine kinase}

Bruton's tyrosine kinase (Btk) also plays an important role in carcinogenesis (Figure 4). It is a key point in signal transduction from the BCR receptor leading to the activation of the NF-kB signaling pathway [54]. Btk affects phospholipase $\mathrm{C} \gamma 2$ [55], which after phosphorylation causes PIP2 hydrolysis. The result 
is IP3 and DAG. DAG activates protein kinase $C \beta$, which stimulates NF-kB pathway factors. Finally, genes conditioning cell survival are expressed. Btk also contributes to inhibiting the apoptosis process through interacting with the Akt kinase [56]. The signaling cascade includes active $\mathrm{PI} 3 \mathrm{~K}$, which recruits $\mathrm{Akt}$ to the plasma membrane. Under the influence of Btk, its phosphorylation occurs, and thus its activation. Then, the active Akt returns to the cytoplasm and induces anti-apoptotic pathways dependent on NF-kB, among others. In addition, Btk, as a kinase belonging to the Tec family, affects intercellular signaling, causing changes in the tumor microenvironment. In most cancer cells, the developing microenvironment leads to the inhibition of immune processes, which results in protection, and protects defective cells from natural defense mechanisms. One of the most common mechanisms of this type is the effect of cancer cells on the increased differentiation of $\mathrm{T}$ lymphocytes towards $\mathrm{Th} 2$ cells. The biological role of these cells is the secretion of interleukins that start a humoral response dependent on B lymphocytes. Due to the increased differentiation of $\mathrm{T}$ lymphocytes in this direction, the number of formed Th1 lymphocytes directly destroying cells containing the abnormal genome decreases. The tumor microenvironment also interferes with normal dendritic cell activity. It inhibits their ability to migrate and to present the antigen to immune response cells. Some types of cancer show increased CXCL12 expression [57], which attracts immature dendritic cells and prevents their differentiation. In addition, this cytokine via the CXCR4 receptor causes a reorganization of the cytoskeleton [58] and increases cell motility [59], Tec family tyrosine kinases have also been shown to have the ability to activate CXCR4, which determines the growth, survival, and migration of tumor cells [60].

\section{FABPs: fatty acid-binding proteins}

The fatty acids supplied to the cell are involved in its metabolism. Due to their lipid nature, they are

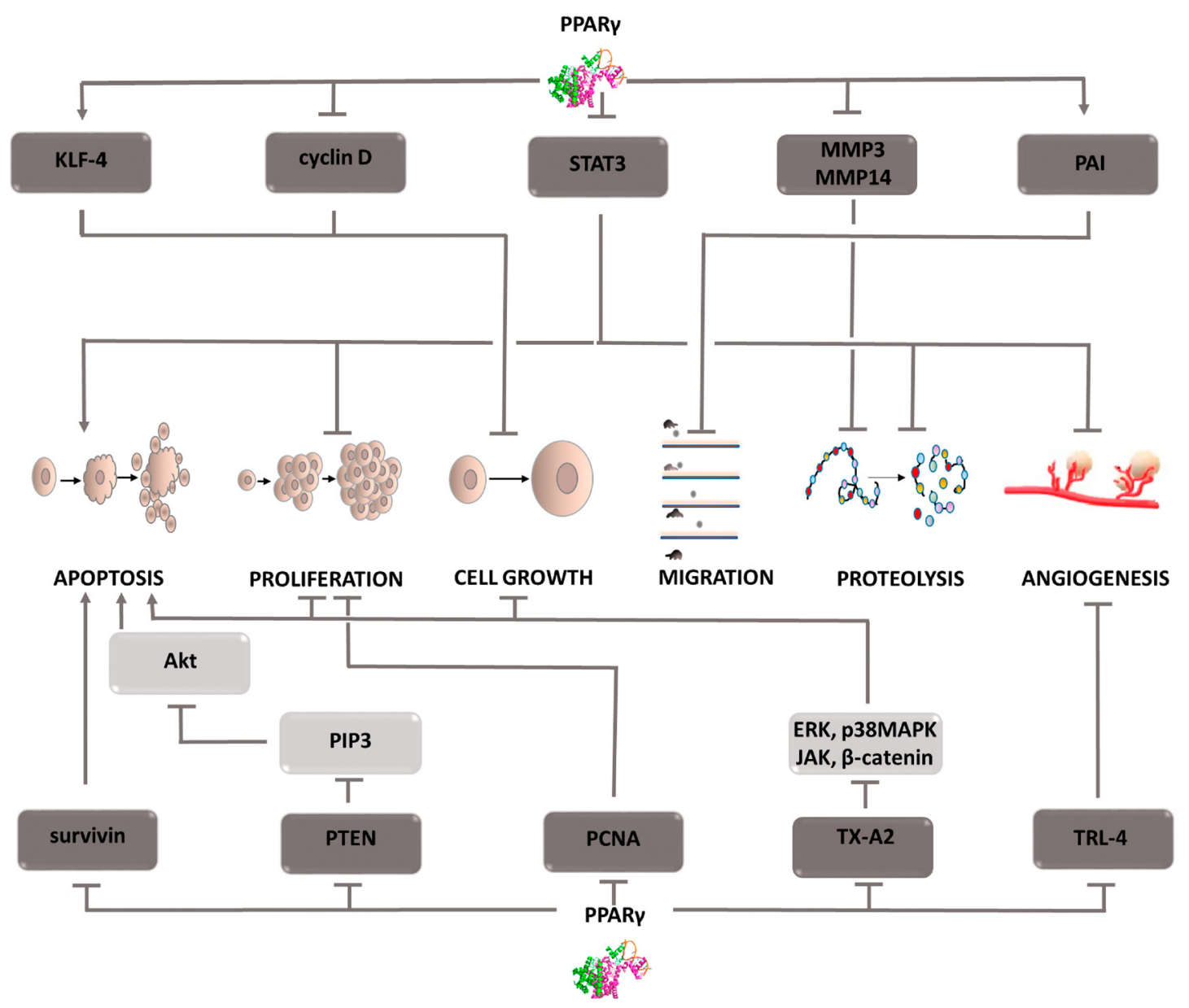

Figure 3: Carcinogenic effect of peroxisome proliferator-activated receptors (PPAR- $\boldsymbol{\gamma}$ ). The induction of the process is illustrated by arrows, the inhibition by the horizontal line. PTEN: phosphatase and tensin homolog deleted on chromosome ten; PIP3: phosphatidylinositol (3,4,5)-trisphosphate; Akt: protein kinase B; PCNA: proliferating cell nuclear antigen; TX-A2: thromboxane A2; ERK: extracellular signal-regulated kinases; p38MAPK: P38 mitogen-activated protein kinases; JAK: Janus-activated kinases; KLF-4: Kruppel-like factor 4; STAT3: Signal transducer and activator of transcription 3; MMP3,14: metalloproteinase 3 or 14; PAI: Plasminogen activator inhibitor; TRL-4: toll-like receptor 4; MAPK: mitogen-activated protein kinase. 
unable to enter the aqueous environment of the cellular cytoplasm. Solubilizing molecules, i.e., fatty acidbinding proteins (FABPs), enable their transport to various cellular structures and thus become involved in the processes taking place in the cells, including their growth, reproduction, and inflammatory processes. In cells characterized by intensive lipid metabolism, such as the liver, intestine, heart, brain, etc., high transporter expression is observed, which is associated with their physiological role in the cell. Depending on the type of cancer, both the overexpression and a decrease in FABPs can be seen. FABP isoforms are not specific to one type of cancer, and each plays a different role in the carcinogenesis process (Figure 5). In liver cancer, L-FABP was overexpressed and its high concentration was shown to correlate positively with VEGF-A [61-63]. The causes of this phenomenon are sought in the direct interaction between these two proteins, which in effect provokes the activation of the $\mathrm{Src} / \mathrm{FAK} / \mathrm{cdc} 42$ and the Akt/ mTOR/P70S6K/4EBP1 signaling pathways. Activation of the Src/FAK/cdc42 pathway increases tumor cell migration, and L-FABP plays a key role in this process $[64,65]$. Moreover, by stimulating the second mentioned signaling cascade, L-FABP enhances VEGF-A expression, facilitating angiogenesis. This process is regulated by HIF$1 \alpha$, which additionally induces blood vessel formation [66]. Due to the high homology in their construction, FABP3 and FABP4 isoforms were assigned to the same protein subfamily. In addition to their physical features, it has been observed that the same factors, i.e., HIF $1 \alpha$, VEGF, increase their co-expression. The physiological role of both proteins is to inhibit excessive cell proliferation and increase apoptosis. Excessive FABP3 expression leads to an increase in reactive oxygen species and a decrease in the mitochondrial membrane potential [67], resulting in the opening of mitochondrial megachannels, which play a key role in initiating apoptosis. FABP4 activates the apoptosis process by mediating the response to lipid-induced endoplasmic reticulum stress. Due to the biological functions of both proteins, their deficiency may be the cause of cancer progression. When examining the level of FABP3 expression in embryonic tumor cells, breast cancer cells [68], and FABP4 in breast, ovarian, prostate, bladder or liver cancer cells, low levels of both proteins were observed, which was associated with a worse prognosis in terms of overall survival. Furthermore, high FABP4 levels slowed the development of hepatocellular carcinoma and thus contributed to its reduction in size [69]. This effect is explained by the inhibition of STAT3 phosphorylation via the Ras-pSTAT3 signaling pathway and the inhibition of the Snail protein, an accelerator of the epithelial-mesenchymal transition [69]. However, the increased FABP3 expression in tumors of the stomach, brain, small- and non-smallcell lung cancer seems paradoxical; it has been shown to increase tumor aggressiveness and poorer patient prognosis $[70,71]$. Thus far, the molecular mechanism responsible for the oncogenic potential of FABP3 and FABP4 is unknown. Further research is needed to clarify the reasons these proteins promote the neoplastic process. Another subtype of fatty acid binding proteins is FABP5. It is involved in the development of breast, prostate, liver, stomach, and colon cancers. FABP5 has been shown to transport saturated and unsaturated long-chain fatty acids that act as PPAR $\beta / \delta$ ligands $[72,73]$. The nature of the supplied fatty acids determines the oncogenic activity, if unsaturated fatty acid or a suppressor action is supplied to $\operatorname{PPAR} \beta / \delta$, in the case of saturated ligands [72]. When the

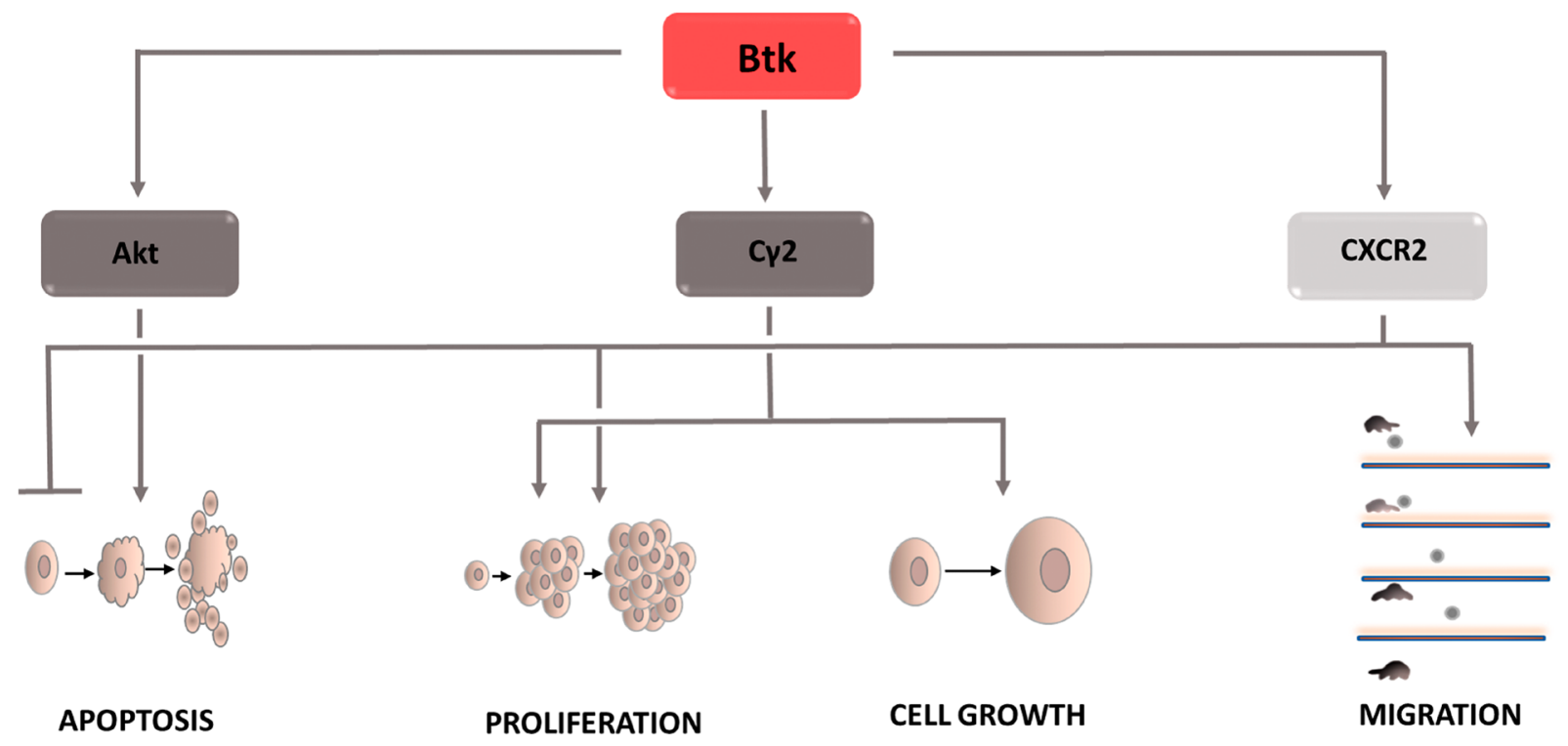

Figure 4: Carcinogenic effect of Bruton's tyrosine kinase (Btk). The induction of the process is illustrated by arrows, the inhibiton by the horizontal line. Btk: Bruton's tyrosine kinase; CXCR2: C-X-C chemokine receptor type 2; C $\gamma 2$ : phospholipase C $\gamma 2$. 
FABP5/PPAR $\beta / \delta$ pathway is stimulated, the transcription of the genes responsible for cell growth and survival increases. Moreover, one of the target genes stimulated by $\mathrm{PPAR} \beta / \delta$ is the FABP5 gene, which increases the expression of the transport protein in question [74]. In prostate cancer cells, by supplying long chain fatty acids, FABP5 leads to PPAR $\gamma$ activation [75-78]. Stimulation of these receptors results in increased expression of vascular endothelial growth factor (VEGF), thereby accelerating the angiogenesis process. This mechanism plays a key role in the development of castration-resistant prostate cancer [79-81]. In the case of colon cancer, FABP5 contributes to its development by reducing p21 activity. Overexpression of FABP5 increases the expression of c-MYC, which inhibits the action of a cell cycle inhibitor. After silencing FABP5 activity, a significant reduction in the invasive capacity of colon cancer cells (CRC) is observed [82]. The molecular basis of this interaction is not yet known at the moment. High expression of monoacylglycerol lipase (MAGL), responsible for the production of free fatty acids, is observed in highly malignant colon cancer cells $[83,84]$. This fact combined with the physiological role of
FABP5, consisting of transporting free fatty acids to the appropriate cell compartments, prompts to seek the answer to the question whether FABP5 and MAGL come into functional interaction with each other, and if so, how does this affect CRC progression. Another FABP isoform that may be involved in colon cancer development is FABP6 [85-87]. It transports bile acids between the epithelial cells of the large intestine, which are transformed into secondary metabolites such as deoxycholic acid (DCA) and lithocholic acid via cellular metabolism. A correlation was demonstrated between increased exposure of intestinal epithelial cells to DCA and an increase in reactive oxygen species inside them which is associated with oxidative stress development and DNA damage [88-90]. This mechanism contributes to the formation of mutations that in the event of a replication of defective cells initiate their malignancy. Due to their detergent properties, bile acids can cause damage to the cell membrane. Compensatory mechanisms lead to an intensified inflammatory response and increased proliferation, which is qualified as early tumor development. Furthermore, bile acids activate the muscarinic M3 receptor [91-93]. Its stimulation induces

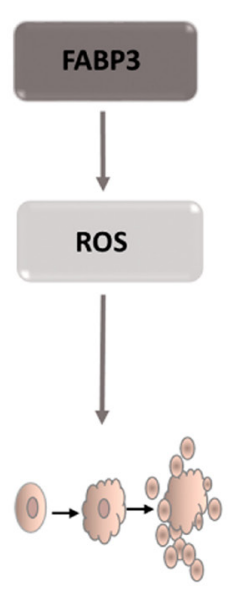

APOPTOSIS
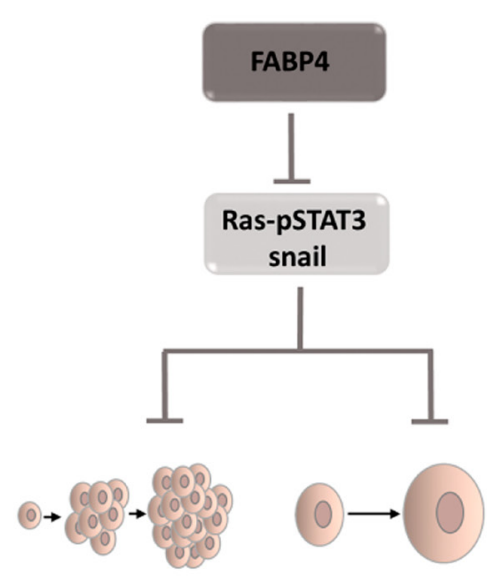

PROLIFERATION

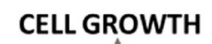

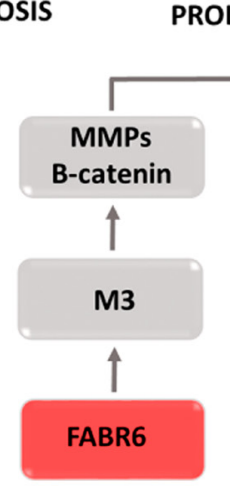
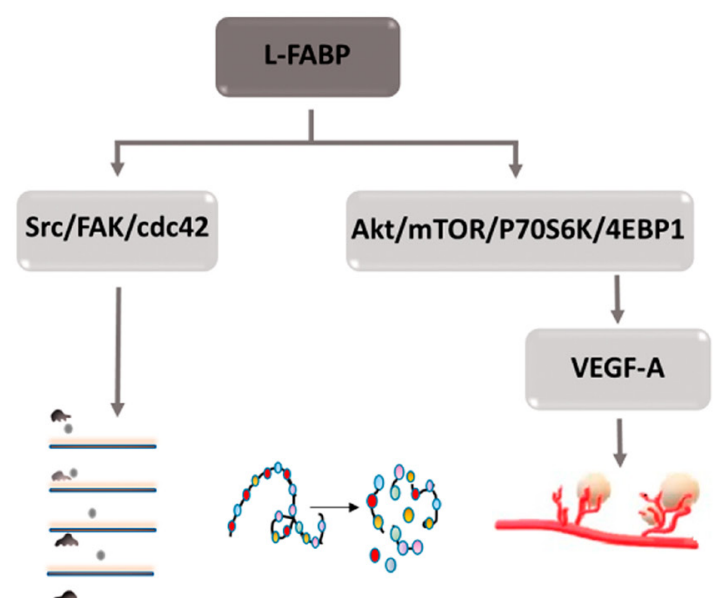

MIGRATION

PROTEOLYSIS
ANGIOGENESIS

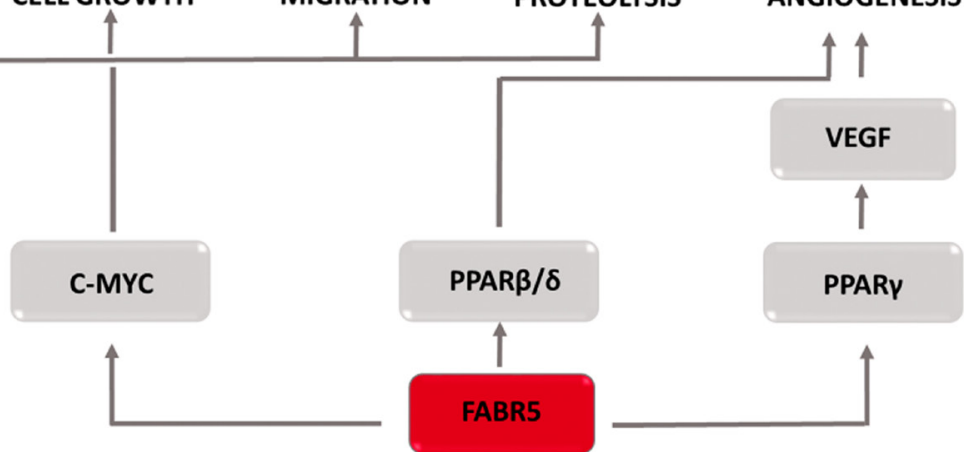

Figure 5: Carcinogenic effect of fatty acid binding proteins (FABPs). The induction of the process is illustrated by arrows, the inhibition by the horizontal line.STAT3: signal transducer and activator of transcription 3; Src: proto-oncogene tyrosine-protein kinase Src; FAK: focal adhesion kinase; cdc42: cell division control protein 42 Homolog; Akt: protein kinase B; mTOR: mammalian target of rapamycin; P70S6K: p70 ribosomal protein S6 kinase; 4EBP1: eukaryotic translation initiation factor 4E (eIF4E)-binding protein 1; VEGF-A: vascular endothelial growth factor-1; M3: muscarinic receptor 3; MMPs: metalloproteinases; PPAR $\gamma$ : peroxisome proliferatoractivated receptors $\gamma$; PPAR $\beta / \delta$ : peroxisome proliferator-activated receptors $\beta$ or $\delta$. 
metalloproteinase activity and the Wnt/B-catenin signaling pathway, which in turn increases the metastatic potential as well as the proliferation and survival of colon cancer cells. Despite the increasing evidence and attempts to explain the mechanisms of FABP action in specific types of cancer, further research is needed to better understand the diagnostic and therapeutic value of these proteins.

\section{AQPs: aquaporins}

Aquaporins (AQPs) are channels responsible for the transcellular transport of water, glycerol, hydrogen peroxide, and other small water-soluble particles. Due to the transported molecules, the family of these 13 proteins can be divided into two subgroups, those that transport only water and those that additionally have the ability to carry glycerol [94]. Regardless of belonging to one of the two described subgroups, aquaporins can participate in $\mathrm{H}_{2} \mathrm{O}_{2}$ transport, which, as it turns out, is of considerable importance in the neoplastic process (Figure 6) [95, 96]. Research conducted on various types of cancer cells, including colon [97], ovarian, [98] brain, [99] lung [100], and pancreatic cancers [101], have shown a correlation between increased aquaporin expression and the level of tumor growth [102]. For this reason, aquaporins have become of interest to researchers exploring processes that play a key role in this pathological process. Tumor cell migration is a stage of disease development in which aquaporins are involved by performing their primary function, i.e., water transport. The migrating cell is characterized by structure polarization and varying build of the leading edge and its end, the so-called uropod. It was observed that aquaporin expression mainly concerns the leading edge, in which the increased influx of water facilitates lamellipodia formation [103, 104]. These structures are the driving force for the wandering cell, and also participate in attaching it to the base in a new site in the body [105]. It is also suspected that aquaporins affect a cell's ability to migrate through the osmotic engine mechanism [106, 107]. The inflow of water and ions at one end of the cell, and their outflow from the opposite pole can cause motion in and of itself. Moreover, by regulating cell hydration, aquaporins determine its size and shape. The outflow of water causing rapid cell reduction significantly facilitates their squeezing through narrow intercellular spaces and reaching hard to reach places. It is important to note that transporters only support cellular migration, they are not its key perpetrators. Therefore, their inhibition will not completely stop cell movement, but gives hope for its significant reduction. The migration process is also involved in the ability of cells to infiltrate local tissues surrounding a growing tumor [108]. The argument demonstrating the involvement of aquaporins in infiltrate formation is their increased expression in cells that form a tumor's surface layer, i.e., the one that is capable of infiltration. However, because the mechanism by which these transporters contribute to increased infiltration is unknown, this area remains a field that is requires research. Cell migration pertains to not only cancer cells, it is also a necessary process for effectively rebuilding and creating blood vessels. Because it occurs on the same principle as metastasis, aquaporin activity may be connected with the angiogenesis process. Through their involvement in angiogenesis and cellular migration, these proteins contribute to tumor growth and progression. Cell proliferation, in which aquaporins are directly and indirectly involved, also contributes to tumor growth. The indirect activity involves stimulating signaling pathways such as Ras or EGFR/ERG/p38 MAPK which contribute to the growth and differentiation of propagated cells [109, 110]. The direct activity is associated with the intracellular transport of glycerol. Since glycerol metabolism is associated with ATP production, it seems that it is a source of energy necessary for life processes, especially in the case of rapidly dividing cells $[111,112]$. Due to the ability of quick adaptation and utilization of the available nutrients for cancer cells' own needs, this mechanism seems to be extremely important. An important aspect of the role of aquaporins in intensifying tumor development is their participation in the transport of hydrogen peroxide, which as a representative of reactive oxygen species is involved in proliferation, differentiation, migration, and adaptation to hypoxia or apoptosis. $\mathrm{H}_{2} \mathrm{O}_{2}$ is involved in PTEN oxidation, which in turn activates the PI3K/Akt pathway promoting cancer cell survival $[113,114]$. This mechanism illustrates the role of hydrogen peroxide as a secondary messenger. Another example confirming this role of $\mathrm{H}_{2} \mathrm{O}_{2}$ is a study that showed the inhibition of Erk and Akt kinase activity, and thus the weakening of the effects of the EGF pathway after NOX inhibitor administration, the enzyme responsible for reactive oxygen species formation [115]. The role of hydrogen peroxide, and through it aquaporins, in migration and angiogenesis is shown by a study that proved that the targeted cell movement induced by the CXCL12 chemokine requires the presence of both factors [116]. Silencing AQP3 activity inhibits the morphological changes of cells necessary for their movement, while the inhibition of NADPH oxidase, an enzyme responsible for reactive oxygen species formation, prevents actin polymerization on the cell's leading edge [116, 117]. Stopping these processes significantly limits cell motility and prevents metastasis or blood vessel remodeling. Another mechanism thanks to which $\mathrm{H}_{2} \mathrm{O}_{2}$ promotes metastasis is its effect on HIF1-a under hypoxic conditions. The intracellular increase in hydrogen peroxide concentration has a stabilizing effect on HIF1-a enabling it to translocate into the cell nucleus and to induce transcriptional activity, consisting of Met oncogene stimulation, among others [118-120]. Through it, cells acquire a phenotype that favors features responsible for their invasiveness. The above examples indicate that aquaporins play an important and complex 
role in intensifying the neoplastic process. For this reason, it can be assumed that therapeutic strategies incorporating inhibitors of these transporters will improve patient outcomes. It should not be forgotten that in many situations aquaporin activity inhibition is only of an auxiliary nature, therefore research is needed to help understand which drug combinations will allow to obtain optimal results. Interest in these structures in terms of oncological treatment is relatively new, which is why there is a need for in-depth research that will help detect possible limitations and potential risks associated with therapy based on aquaporin inhibitors.

\section{IGF-2: insulin-like growth factor 2}

The physiological role of (IGF-2) is to regulate embryonic development. This factor is one of the elements of the complex signaling system, which consists of insulin; two isoforms of its receptor, IR-A, IR-B; insulin-like growth factors, IGF-1, IGF-2; their receptors, IGF-1R, IGF-2R; and two subfamilies of proteins binding this factor, IGFBPs, IGF2BPs. Studies conducted on various types of tumor cells have shown IGF-2 overexpression and increased IGF-1R receptor prevalence [121-123]. This fact is associated with a worse prognosis, shorter survival, and the development of resistance to chemotherapy [124, 125]. Studies conducted to clarify the mechanism of IGF2 activity have shown that it is necessary to understand the role of the individual components of the insulin/IGF signaling axis. Its elements mutually affect their activity, thereby modulating the final effect. Despite the structural similarities between IGF-1 and IGF-2, their functions differ significantly, indicating greater IGF-2 involvement in the oncogenesis process. Tumor cells produce IGF-2, which has the ability of autocrine and paracrine stimulation of the IGF-1R receptor [126, 127]. Furthermore, they secrete immature IGF-2, i.e., large IGF-2, which has the ability to stimulate the same receptors as IGF-2 and is

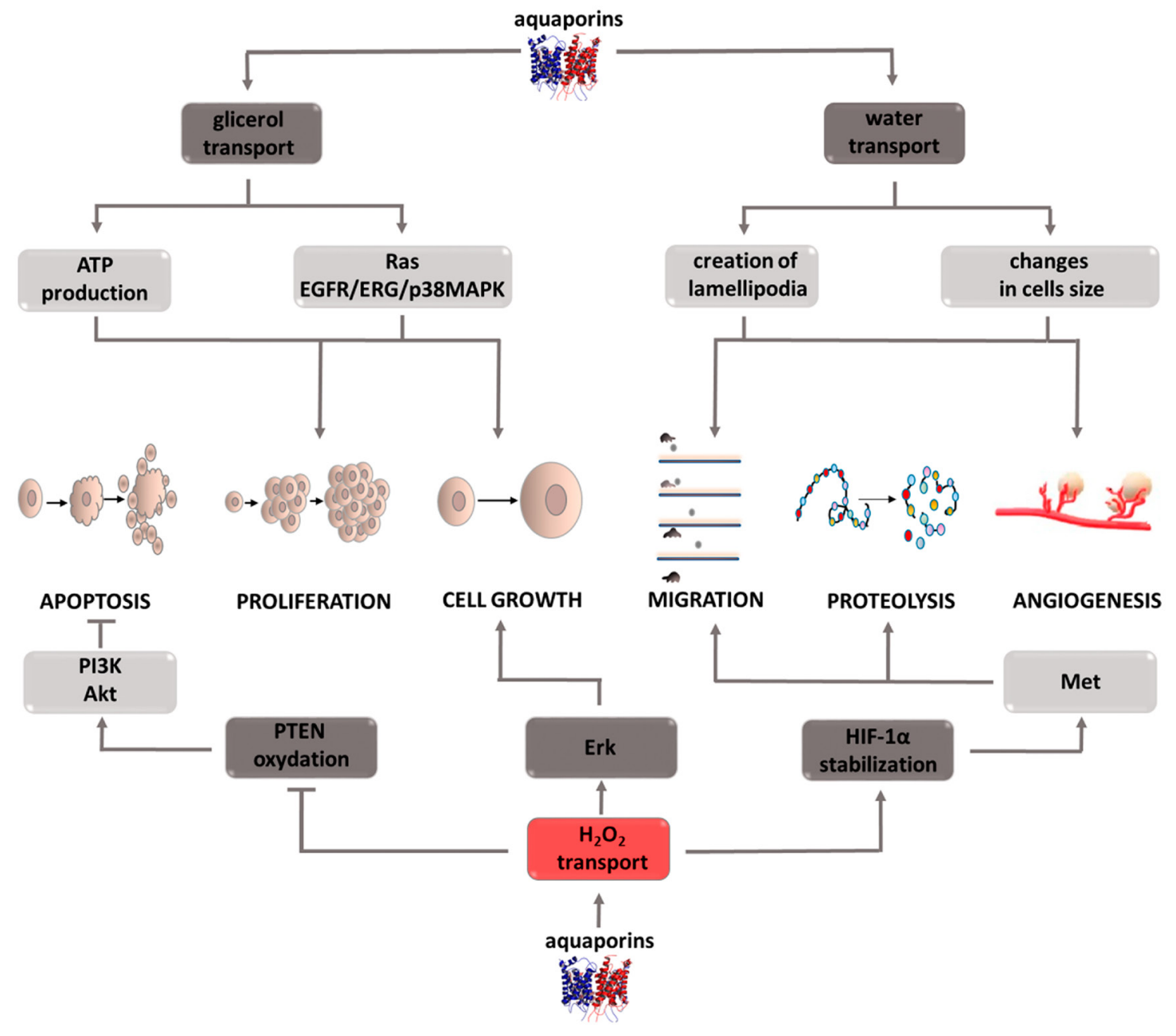

Figure 6: Carcinogenic effect of peroxisome aquaporins (AQPs). The induction of the process is illustrated by arrows, the inhibition by the horizontal line. PTEN: phosphatase and tensin homolog deleted on chromosome ten; PI3K: phosphoinositide 3-kinase; Akt: protein kinase B; ERK: extracellular signal-regulated kinases; HIF-1 $\alpha$ : hypoxia-inducible factor 1-alpha; Met: tyrosine-protein kinase Met; ATP: adenosine triphosphate; EGFR: epidermal growth factor receptor; ERG: erythroblast transformation-specific related gene; p38MAPK: P38 mitogen-activated protein kinases. 
not susceptible to degradation when combined with the specific IGF-2R receptor. Thus, tumor cells gain the ability to stimulate the signals involved in the survival processes even in the presence of a suppressor protein. One of the main effects of IGF-2 is IGF-1R receptor stimulation, leading to autophosphorylation of the $\beta$-subunit, recruitment of the insulin receptor substrate (IRS), and activation of the Akt, MAPK signaling pathways (Figure 7) [128]. IGF-2 stimulation of the IR-A receptor has a similar effect. The active Akt kinase inactivates the proapoptotic BAD proteins, thus inhibiting cell death. It also enhances the synthesis of the ribosomal proteins necessary for the mitosis process by activating the mTOR pathway and affects the transfer of glucose transporters (GLUT) to the cell surface. As a result, the supply of energy to the dividing cells is increased. Activation of the MAPK pathway, in turn, causes changes in the expression of the protein genes necessary for cell growth. Both pathways serve to support cell life and proliferation. Interesting conclusions were provided by the discovery of Panadini et al. who showed that IGF-2 inhibits the ubiquitination of EphB4 receptor tyrosine kinase by autocrine stimulation of insulin receptor $\mathrm{A}$ isoform. This effect is exerted regardless of IGF-1R receptor stimulation and results in PI3K signaling pathway activation by EphB4 [129]. This explains why therapy based on IGF$1 \mathrm{R}$ inhibitors does not bring the desired results, and tumor cells do not lose the ability to develop, proliferate, and metastasize [130]. Understanding the mechanism of drug resistance and the role of IGF-2 inhibitors in its formation may contribute to the development of a new therapeutic strategy in the fight against cancer. It is currently assumed that the failure of IGF-1R inhibitor therapy is only associated with IR-A receptor stimulation. However, there is no data that would explain whether it can also be caused by the ability to stimulate the hybrid receptor IR/IGF1R by IGF-2. In addition to its effect on signaling cascades, IGF-2 has the ability to inhibit p53 activity, which obviously contributes to the proliferation of cells containing defective genetic material. IGF2 is not only involved in cell proliferation and viability, it also participates in the angiogenesis process by affecting stem cell differentiation toward endothelial cells. Moreover, hypoxia-induced factor enhances IGF-2 expression in conditions of insufficient oxygen supply, which then activates VEGF expression. Thus, IGF-2 contributes to the creation of the optimal tumor microenvironment, which provides it with the transport of factors necessary for growth. As mentioned earlier, the whole system also includes the receptor IGF-2R, which when combined with the ligand leads to IGF-2 degradation. Furthermore, it can release its extracellular domain into the bloodstream, which binds circulating IGF-2, thereby inhibiting its activity. Therefore, this receptor is considered a tumor suppressor factor. The amount of IGF-2 circulating in the circulatory system is regulated by specific proteins called insulin-like growth factor-binding proteins (IGFBPs). It is a family of 6 forms of proteins that modulate IGF2 activity by blocking its binding to the receptor. The expression of individual IGFBPs is tissue-specific, and the induced effects differ. For this reason, it is impossible to assign a specific role in the cancer process to the entire family. For example, IGFBP-5 found in mammary glands inhibits differentiation and enhances the apoptosis process in breast cancer cells. IGFBP-3 in esophageal cancer cells acts as an antioxidant, thereby enhancing tumor cell growth in an IGF-2-independent mechanism [131, 132]. It also affects epithelial-mesenchymal transition, intensifying the formation of cancer stem cells. The second family of proteins that affect IGF-2 are IGF-2 mRNA binding proteins (IGF2BPs), which has three components. Their role in the cancer process is better understood. An increase in IGF2BP3 expression is associated with increased cell invasiveness and greater dynamics of the tumor process IGF2BP2, in turn, stabilizes IGF-2 mRNA, which increases its expression contributing to tumor development [133-135]. These examples indicate how extensive and important a role insulin-like growth factor 2 plays in the cancer process. For this reason, it is fully justified to conduct research enabling the development of pharmacotherapy based on IGF-2 inhibitors. It should not be forgotten that it is a component of a complex signaling system that also regulates physiological processes. Thus, when designing treatment, the dependencies connecting individual components and potential threats resulting from inhibiting the activity of one of the pillars should be taken into account.

\section{Exosomes}

Exosomes are small membrane vesicles secreted by both normal and cancer cells. Acting in an autocrine or paracrine manner, they participate in intercellular communication processes. The basis of this phenomenon is two separate mechanisms, i.e., the delivery of proteins that affect signaling cascades to target cells, or the transport of various micro RNAs (miRNAs) that modulate the expression of individual genes. By affecting tumor transformation, angiogenesis and metastasis, exosomes are one of the factors that accelerate cancer progression (Figure 8). The effect on the transformation of normal cells into malignant cells is mediated by various types of miRNAs that activate oncogenes and inhibit the expression of suppressor genes [136]. Moreover, exosomal miRNAs stimulate receptors in the TLR (Toll-like receptors) family, which leads to a chronic inflammatory response, one of the factors intensifying tumor transformation [137, 138]. In addition, the release of proinflammatory cytokines caused by TLR stimulation leads to neutrophil recruitment in the inflammation area. As a source of reactive oxygen species, neutrophils can destabilize and damage epithelial cell genetic material, thus contributing to their mutation and 
malignancy [139]. Due to the ability to create neutrophil extracellular traps (NETs), they can trap circulating tumor cells (CTCs) and then transport them to areas distant from the primary tumor focus [140-142]. Furthermore, by secreting factors of vascular endothelial activation, neutrophils increase its adhesion, which facilitates the adhesion of the transported CTCs [143-145]. Thus, the formation of metastasis in a region distant from the primary tumor is significantly simplified. The described mechanism combining the effect of exosomes with the effects caused by neutrophils is not the only one by which cell vesicles are involved in the particular stages of tumor development. By directly supplying factors such as VEGF [146, 147] EGFR [148] fibroblast growth factor (FGF) [149] or angiopoietin [150] they contribute to new blood vessels development that ensures the optimal growth environment for the dividing cells. The indirect pro-angiogenic activity is the transport of miR210 through exosomes secreted by tumor cells [151, 152]. Under hypoxic conditions, miR-210 has the ability to inhibit ephrin-A3 receptor tyrosine kinase expression [153-155]. As a result of this interaction, increased secretion of VEGF occurs, which stimulates the formation of new blood vessels $[156,157]$. To stimulate VEGF gene expression, exosomal miR-9 contributes indirectly, which activates the JAK-STAT signaling pathway [158-160]. Thus, STAT3 factor, a direct transcription activator of the VEGF gene, is phosphorylated [161]. The aforementioned neutrophil extracellular traps (NETs) contribute to metastasis formation. Another mechanism involved in this stage of carcinogenesis is the weakening of tight junction intercellular connections by regulating the ZO-1 (zonula occludens-1) gene. Exosomal miR-105 inhibits the expression of this gene, which causes connection loosening and the destruction of the barrier formed by epithelial cells [162-164]. Thus, cancer cells gain access to the blood vessel lumen, which creates the possibility of moving to remote areas of the body. The down regulation of cadherin-17 expression induced by exosomal miR-494 and miR-542-p transport also favors migration [165, 166]. A decrease in the concentration of this protein leads to an increase in metalloproteinase concentration, thereby increasing their activity. Metalloproteinase activity also increases via the Fas/Fas2 signaling pathway [167-169].

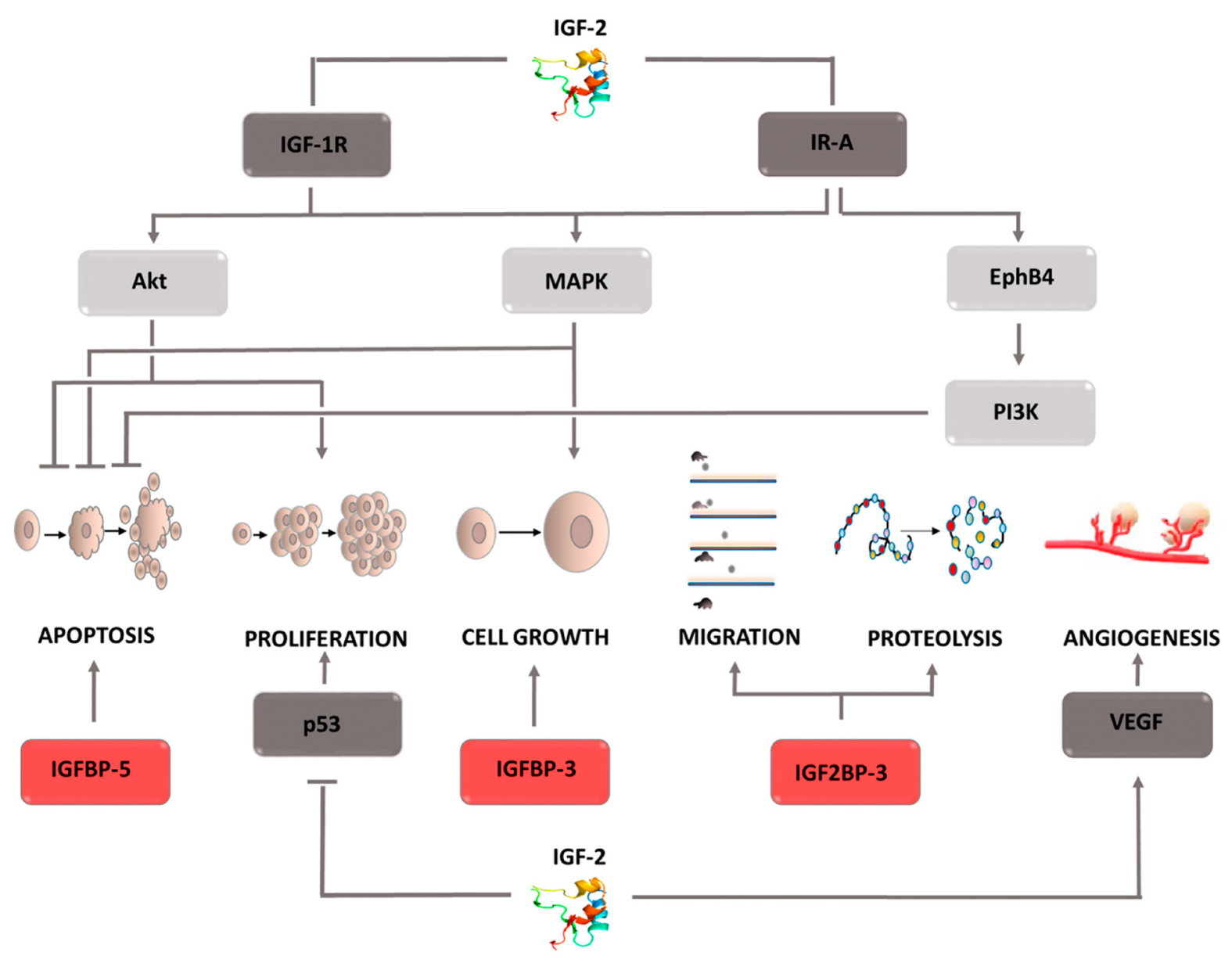

Figure 7: Carcinogenic effect of insulin like factor- 2 (IGF-2). The induction of the process is illustrated by arrows, the inhibition by the horizontal line. IGF-1R: insulin-like growth factor receptor 1 or 2; IR-A: insulin receptor A; VEGF: vascular endothelial growth factor; EphB4: Ephrin type-B receptor 4; Akt: protein kinase B; MAPK: mitogen-activated protein kinase; PI3K: phosphoinositide 3-kinase; IGFBP 3,5: insulin-like growth factor-binding proteins 3 or 5; IGF2BP3: insulin like growth factor-2 mRNA binding proteins 3. 
When transporting the Fas ligand to the target cell, exosomes contribute to the activation of the Fas/Fas2 pathway, and thus increase the activity of the proteins responsible for the reorganization of the extracellular matrix $[170,171]$. The second effect induced by active metalloproteinases is growth factor release. Thanks to these two mechanisms, enzymes not only facilitate the movement of cancer cells, but also have a positive effect on the angiogenesis process. The described relationships indicate that exosomes are involved in the complex mechanisms leading to the development of the individual stages of carcinogenesis. Therefore, the use of inhibitors of their activity would enable comprehensive inhibition of the tumor progression process. For this reason, these components appear to be an attractive therapeutic target that, if included in the treatment strategy, could bring measurable benefits.

\section{Carcinogenesis modulators: from basic research to clinical practice}

Existing data indicate that all factors considered in this papier represent promising and challenging therapeutic targets. That provides the basis for developing new anticancer drugs or testing known agents that are already used in clinical practice to repurpose their indication. This part of the manuscript provides an overview of the studies that reveal the connection between preclinical knowledge (both in vitro and in vivo) and its practical use.

The AChRs inhibitors intended to provide treatment for irritable-bowel syndrome or overactive bladder are currently being tested in different cancer types. An in vitro study showed that M1 muscarinic receptor antagonist dicyclomine and/or M3 muscarinic receptor antagonis, derifenacine reduced viability and increased apoptosis of chemoresistant lines of non-small cell lung cancer (NSCLC) and prostate cancer (PCa) [172]. In turn, another M3 muscarinic receptor antagonist, aclidinium bromide inhibits growth and limits the metastatic potential of A549-human lung cancer cells [173]. Witayateeraporn et al. also showed the potential benefits of anticholinergic treatment in cancer therapy. They tested four nAChR inhibitors (QND7, PPRD10, PPRD11, and PPRD12) on two cell lines of NSCLC (H460, A549) and indicated that QND7 showed the most significant cytotoxic effect, induction of apoptosis and lowering cell migration. The authors suggested mTOR/Akt pathway involvement in the antitumor effect of QND7 [174]. Promising outcomes are also provided by the studies conducted on the Swedish population. An inversely proportional relationship was established between exposition on antimuscarinic treatment, using compounds such as oxybutynin, solifenacin, darifenacin, fesoterodine, or tolterodine and the risk of colon or lung cancer [175].

Rosiglitazon, a widely used PPAR $\gamma$ agonists, has been tested in a number of oncological studies. An in vitro study on two breast cancer cell lines (A2780, SKOV3) revealed severe apoptosis and tumor growth inhibition in mouse xenografts after combined therapy of rosiglitazone and olaparib [176]. Rosiglitazone also decreased proliferation and tumor size in human squamous cell carcinoma (SCC) xenografts [177]. In turn, Lau et al. demonstrated the synergistic impact of rosiglitazone on 5-fluorouracil-induced apoptosis of two colorectal cancer cell lines (HCT-116, HT-29). The effect of this combination was significantly stronger compared to 5-FU in monotherapy [178]. Another, PPAR $\gamma$ agonist, trioglitazone significantly suppressed the growth of human oral squamous cell carcinoma cell lines (HSC-4, Ca922) by inducing cell cycle arrest [179]. The efficacy of rosiglitazone and pioglitazone, has also been evaluated on bladder cancer cells. Both drugs induced cell cycle arrest and decreased proliferation of two tested cell lines Umuc3 and 5637. Pioglitazone, also appeared to be effective in relation to melanoma. The results of an animal study show that pioglitazone inhibits subcutaneous tumor growth in a mouse xenograft model of murine melanoma B16F10 cells [180]. Moreover pioglitazone in combination with rofecoxib and trofosfamide were also active and well tolerated in patients with chemorefractory melanoma and soft tissue sarcoma [181].

Therapy with Btk inhibitors and its potential benefits are now in development. Combination therapy of ibrutinib (Btk inhibitor) and 5-FU resulted in an increase in the cytotoxicity of 5-FU resistant human colorectal cancer. Similarly, other Btk inhibitors (AVL-292, RN486, CGI1746, ONO-40590) used in the combination with 5-FU also inhibited the growth of these cells via enhancement of apoptosis. Moreover, a cytotoxic response was obtained on patient-derived 3D organoids after the administration of 5-FU with ibrutinib or AVL-292 [182]. In the mouse xenograft model resensitization to 5 -FU in HCT116p53KO cells in the presence of ibrutinib was observed [182]. In turn adding erythropoietin to LFM-A13 (Btk inhibitor) significantly intensified the anticancer action of LFM-A13 in colon cancer xenografts [183]. BTK inhibitors were generally evaluated on hematological malignancies. Ibrutinib is currently approved for use in patients with chronic lymphocytic leukemia (CLL) or mantle cell lymphoma (MCL) and has an established safety record from clinical trials in these patient populations. An increasing body of experimental and clinical data from recent years supports the major role of Btk not only in B cell malignancies [184] but also in other solid tumors, including breast [185], ovarian [186], and prostate cancer [187].

The described role of FABPs depicts them as agents that play a double role in carcinogenesis. Therefore, selectivity for each isoform may prove to be a key determinant of the pro/antitumor role of potential therapeutic drugs. The literature data indicate berberine as the inhibitor of FABPs expression. Human gastric cancer 
cells MGC803 and MGC803 xenografts were exposed to its action. Both in vitro and in vivo results indicate increased apoptosis and inhibition of proliferation. Another tested FABPs inhibitor BMS309403 also exerted antiproliferative activity and limited tumor growth. Simultaneous use of both compounds generated stronger growth inhibition compared to administered alone [188]. Hsiao et al. observed FABP5 mRNA suppression and HT29 cell migration inhibition after pterostilbene treatment. They emphasized that pterostilbene, as a FABP5 inhibitor, can serve to mitigate adiposity-induced metastasis in CRC [189]. Additionally a clinical trial to assess megestrol acetate with or without pterostilbene in treating patients with endometrial cancer undergoing hysterectomy is ongoing.

As mentioned above, AQPs inhibition could be helpful in supporting anticancer therapy, especially in terms of metastasis. A recent study demonstrated furans as a new class of AQP1 ion channel inhibitors that block slow cancer cell migration and invasion. An in vitro study on cell cultures with different expressions of AQP1 showed that 5HMF (5-hydroxymethyl furfural) significantly reduced the migration of cells with high AQP1 expression (colon cancer cell HT-29, breast cancer cell MDAMB-231) without causing changes in cells lacking AQP1 expression (colon cancer cell SW480) [190]. Similar results were obtained in a trial that evaluated the effect exerted by AqB011 and bacopaside II in monotherapy or in combination. Both compounds were identified as AQP1 inhibitors with two different mechanisms of action. AqB011blocks the ion pore of AQP1, whereas bacopaside II targets the water pore, which prevents a water flux.

The attenuation of HT-29 cell migration in monotherapy has been demonstrated as well as a significant improvement of this process in combined therapy. Moreover, a decreased invasiveness of cells was observed after bacopaside II treatment [191]. A similar effect was demonstrated in colon cancer cells (HCT116, SW480) after AQP-5 knock-down with specific shRNA [192]. The anti-cancer activity of the extracts bacopaside $\mathrm{I}$ and bacoside A in mouse models of melanoma, sarcoma and Ehrlich ascites carcinoma was also shown. Existing data concerning other forms of AQPS indicated that auphen (AQP3 inhibitor) decreased expression of AQP3 aquaporins and suppressed the development and tumor growth of xenografts of the HCC cell line [193].
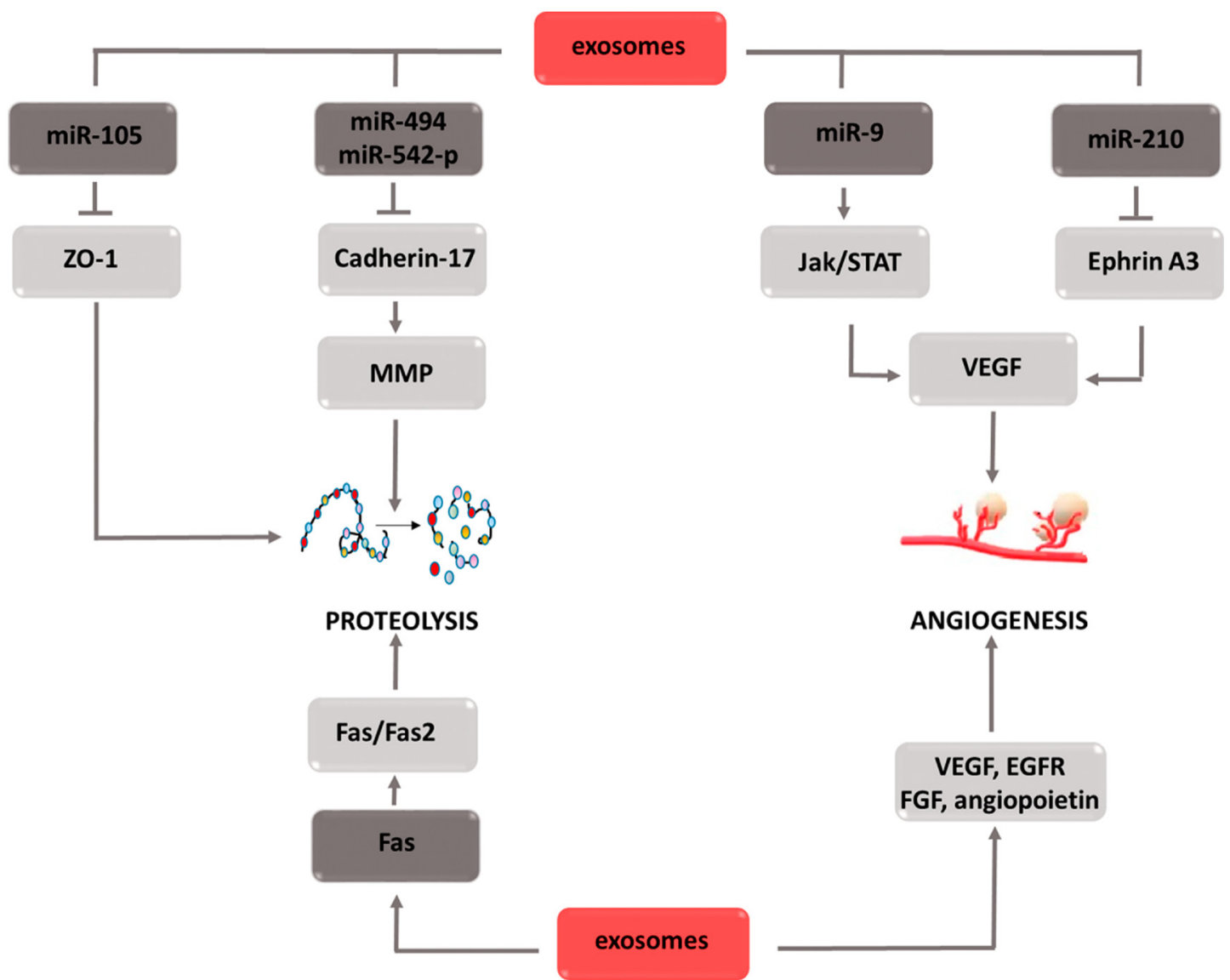

exosomes

ANGIOGENESIS

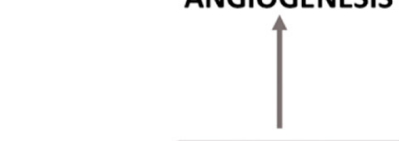

VEGF, EGFR

FGF, angiopoietin

Figure 8: Carcinogenic effect of exosomes. The induction of the process is illustrated by arrows, the inhibition by the horizontal line. miR: micro ribonucleic acid; ZO-1: zonula occludens-1; MMPs: metalloproteinases; JAK: Janus-activated kinases; STAT: signal transducer and activator of transcription; VEGF: vascular endothelial growth factor; FGF: fibroblast growth factor; EGFR: epidermal growth factor receptor. 
The next factor considered in the manuscript, that can be a potential antitumor target is IGF-2. Xentuzumab (IGF ligand-neutralizing antibody) was examined in monotherapy or in combination with enzalutamide on five prostate cancer cell lines (VCaP, DuCaP, MDA PCa 2b, LNCaP, and PC-3). In both therapeutic options cell viability was significantly decreased in all tested cell lines. Moreover xentuzumab + enzalutamide inhibited the growth of castration-resistant LuCaP 96CR PDX with acquired resistance to enzalutamide, and improved survival in vivo [194]. Nevertheless the addition of xentuzumab to enzalutamide did not prolong progressionfree survival in patients with metastatic castration-resistant prostate cancer compared with enzalutamide alone [195].

Exosomes based therapy can be focused on a few mechanisms of action. Potentially useful molecules can act as the inhibitors of endocytosis (i.e., heparin, cytochalasin $\mathrm{D}$, methyl- $\beta$-cyclodextrin), limit cell membrane fusion or limit their biogenesis and release (in this approach Rab proteins, as the biogenesis modulators can be targeted) [196]. Because of the role of exosomes as the communicators between cells, they can be used as well, to transport antitumor molecules. For the internalization exosomes bind with HSPG (Heparan sulfate proteoglyca), which also binds with heparin [197]. Interaction between heparin an HSPG concurs with exosomes binding, thus disturbs theirs uptake. From this reason heparin is tested as a potential anticancer agent. Pretreatment oral squamous carcinoma cells (OSCC) with heparin allowed for temporary inhibition of exosomes uptake. In turn multiply heparin administration significantly reduced cells' proliferation, migration and invasiveness. This observation has been repeated in vivo, on xenograft nude mice model, in which constant heparin infusion decreased tumor growth [198]. Anticancer effect of heparin was observed also in the urothelial cells treated with muscle-invasive bladder cancer- derived exosomes (MIBC). Incubation of primary urothelial cells with MIBC exosomes increased theirs migration, what was reversed after heparin pretreatment [199]. As mentioned before, molecules which can be essential in exomes release are Rab proteins, which control exocytosis. Especially, Rab11, 27a/b, 35 are involved in this process [200]. It was shown that in the prostate cancer cells tipifarnib (farnesyltransferase inhibitor) decreased level of Rab27a, with following inhibition of exosomes' release. Similar effect was gained on the same cell line after administration of neticonazole, climbazole and ketoconazole [201]. The latter is already use as a second-line strategy in castration-resistant prostate cancer [202]. Neticonazole lowered exosomes serum level induces apoptosis and inhibits tumor growth in colorectal cancer xenograft mouse model [203]. Tipifarnib as a monotherapy of metastatic head and neck squamous cell carcinoma (HNSCC) bearing HRAS mutation in the II phase of clinical trial showed durable response and lack of progression in most of the patients [204].

\section{CONCLUSIONS}

The pathogenesis of cancer is extremely complex and depends on many factors. Often, one element affects several stages of carcinogenesis, and individual stages are regulated by many stimuli. This may be an explanation for the difficulties in conducting effective cancer therapy. Pharmacological inhibition of one way of development in a way forces cancer cells to incorporate other mechanisms that will enable their survival. On the other hand, the multifaceted action of the described causative agents gives hope that the use of targeted substances can contribute to the inhibition of key life processes and stop tumor growth. In-depth knowledge of the role of individual carcinogenesis modulators creates the basis for the development of new drugs that may prove to be an effective weapon in the fight against cancer. Moreover, this knowledge may enable the right selection of drug binding sites in the development of combination therapy and contribute to safer treatment with fewer side effects. The constantly growing dynamics of cancer spread indicates for a need to also intensify research in the aspect of factors modulating the carcinogenesis process. Full understanding of the mechanisms responsible for carcinogenesis is an extremely difficult challenge, but it is necessary in an effective fight against cancer.

\section{Author contributions}

Conceptualization: JMH; resources: JMH; writing, original draft preparation: JMH, IK; writing, review and editing: DP; supervision: DP; project administration: JMH, DP; funding acquisition: DP. All authors have read and agreed to the published version of the manuscript.

\section{CONFLICTS OF INTEREST}

The authors declare no conflicts of interest.

\section{FUNDING}

This research was funded by the National Science Center, Poland grant number 2018/31/B/NZ7/00875.

\section{REFERENCES}

1. Latest global cancer data: Cancer burden rises to 18.1 million new cases and 9.6 million cancer deaths in 2018, World Health Organization.

2. Patterson AD, Gonzalez FJ, Perdew GH, Peters JM. Molecular Regulation of Carcinogenesis: Friend and Foe. Toxicol Sci. 2018; 165:277-283. https://doi.org/10.1093/ toxsci/kfy185. [PubMed]

3. Yang J, Nie J, Ma X, Wei Y, Peng Y, Wei X. Targeting PI3K in cancer: mechanisms and advances in clinical trials. Mol 
Cancer. 2019; 18:26. https://doi.org/10.1186/s12943-0190954-X. [PubMed]

4. Shi X, Wang J, Lei Y, Cong C, Tan D, Zhou X. Research progress on the PI3K/AKT signaling pathway in gynecological cancer (Review). Mol Med Rep. 2019; 19:4529-4535. https://doi.org/10.3892/mmr.2019.10121. [PubMed]

5. Kachrilas S, Dellis A, Papatsoris A, Avgeris S, Anastasiou D, Gavriil A, Horti M, Tseleni Balafouta S, Livadas K, Stravopodis DJ, Alivizatos G, Voutsinas GE, Deliveliotis C. PI3K/AKT pathway genetic alterations and dysregulation of expression in bladder cancer. J BUON. 2019; 24:329-337. [PubMed]

6. Reddy D, Kumavath R, Tan TZ, Ampasala DR, Kumar AP. Peruvoside targets apoptosis and autophagy through MAPK Wnt/ $\beta$-catenin and PI3K/AKT/mTOR signaling pathways in human cancers. Life Sci. 2020; 241:117147. https://doi. org/10.1016/j.1fs.2019.117147. [PubMed]

7. Rodriguez-Aguayo C, Bayraktar E, Ivan C, Aslan B, Mai J, He G, Mangala LS, Jiang D, Nagaraja AS, Ozpolat B, Chavez-Reyes A, Ferrari M, Mitra R, et al. PTGER3 induces ovary tumorigenesis and confers resistance to cisplatin therapy through up-regulation Ras-MAPK/ Erk-ETS1-ELK1/CFTR1 axis. EBioMedicine. 2019; 40:290-304. https://doi.org/10.1016/j.ebiom.2018.11.045. [PubMed]

8. Xie Q, Yu Z, Lu Y, Fan J, Ni Y, Ma L. microRNA-148a$3 p$ inhibited the proliferation and epithelial-mesenchymal transition progression of non-small-cell lung cancer via modulating Ras/MAPK/Erk signaling. J Cell Physiol. 2019; 234:12786-12799. https://doi.org/10.1002/jcp.27899. [PubMed]

9. Cao Z, Liao Q, Su M, Huang K, Jin J, Cao D. AKT and ERK dual inhibitors: The way forward? Cancer Lett. 2019; 459:30-40. https://doi.org/10.1016/j.canlet.2019.05.025. [PubMed]

10. Martínez-Limón A, Joaquin M, Caballero M, Posas F, de Nadal E. The p38 Pathway: From Biology to Cancer Therapy. Int J Mol Sci. 2020; 21:1913. https://doi. org/10.3390/ijms21061913. [PubMed]

11. Rahmani F, Tadayyon Tabrizi A, Hashemian P, Alijannejad S, Rahdar HA, Ferns GA, Hassanian SM, Shahidsales $\mathrm{S}$, Avan A. Role of regulatory miRNAs of the Wnt/ $\beta$-catenin signaling pathway in tumorigenesis of breast cancer. Gene. 2020; 754:144892. https://doi.org/10.1016/j. gene.2020.144892. [PubMed]

12. Shi J, Zhu Q, Wu J, Zhu P. FAM46C suppresses gastric cancer by inhibition of Wnt/beta-catenin. Front Biosci (Landmark Ed). 2020; 25:549-563. [PubMed]

13. Gu J, Cui CF, Yang L, Wang L, Jiang XH. Emodin Inhibits Colon Cancer Cell Invasion and Migration by Suppressing Epithelial-Mesenchymal Transition via the Wnt/ $\beta$-Catenin Pathway. Oncol Res. 2019; 27:193-202. https://doi.org/10. 3727/096504018X15150662230295. [PubMed]
14. Shamsian A, Sepand MR, Javaheri Kachousangi M, Dara T, Ostad SN, Atyabi F, Ghahremani MH. Targeting Tumorigenicity of Breast Cancer Stem Cells Using SAHA/ Wnt-b Catenin Antagonist Loaded Onto Protein Corona of Gold Nanoparticles. Int J Nanomedicine. 2020; 15:40634078. https://doi.org/10.2147/IJN.S234636. [PubMed]

15. Jasim S, Habra MA. Management of Adrenocortical Carcinoma. Curr Oncol Rep. 2019; 21:20. https://doi. org/10.1007/s11912-019-0773-7. [PubMed]

16. Mohrherr J, Haber M, Breitenecker K, Aigner P, Moritsch S, Voronin V, Eferl R, Moriggl R, Stoiber D, Győrffy B, Brcic L, László V, Döme B, et al. JAK-STAT inhibition impairs K-RAS-driven lung adenocarcinoma progression. Int J Cancer. 2019; 145:3376-3388. https://doi.org/10.1002/ ijc.32624. [PubMed]

17. Mumin NH, Drobnitzky N, Patel A, Lourenco LM, Cahill FF, Jiang Y, Kong A, Ryan AJ. Overcoming acquired resistance to HSP90 inhibition by targeting JAK-STAT signalling in triple-negative breast cancer. BMC Cancer. 2019; 19:102. https://doi.org/10.1186/s12885-019-5295-Z. [PubMed]

18. Verhoeven Y, Tilborghs S, Jacobs J, De Waele J, Quatannens D, Deben C, Prenen H, Pauwels P, Trinh XB, Wouters A, Smits ELJ, Lardon F, van Dam PA. The potential and controversy of targeting STAT family members in cancer. Semin Cancer Biol. 2020; 60:41-56. https://doi. org/10.1016/i.semcancer.2019.10.002. [PubMed]

19. Chen J, Cheuk IW, Shin VY, Kwong A. Acetylcholine receptors: Key players in cancer development. Surg Oncol. 2019; 31:46-53. https://doi.org/10.1016/j. suronc.2019.09.003. [PubMed]

20. Sales M, Español A, Salem A, Martínez Pulido P, Sanchez Y, Sanchez F. Role of Muscarinic Acetylcholine Receptors in Breast Cancer: Design of Metronomic Chemotherapy. Curr Clin Pharmacol. 2019; 14:91-100. https://doi.org/10 $.2174 / 1574884714666181203095437$. [PubMed]

21. Goto Y, Ando T, Izumi H, Feng X, Arang N, Gilardi M, Wang Z, Ando K, Gutkind JS. Muscarinic receptors promote castration-resistant growth of prostate cancer through a FAK-YAP signaling axis. Oncogene. 2020; 39:4014-27. https://doi.org/10.1038/s41388-020-1272-x. [PubMed]

22. Wang Z. Transactivation of Epidermal Growth Factor Receptor by G Protein-Coupled Receptors: Recent Progress, Challenges and Future Research. Int J Mol Sci. 2016; 17:95. https://doi.org/10.3390/ijms17010095. [PubMed]

23. Tolaymat M, Larabee SM, Hu S, Xie G, Raufman JP. The Role of M3 Muscarinic Receptor Ligand-Induced Kinase Signaling in Colon Cancer Progression. Cancers. 2019; 11:308. https://doi.org/10.3390/cancers11030308. [PubMed]

24. Yang T, He W, Cui F, Xia J, Zhou R, Wu Z, Zhao Y, Shi M. MACC1 mediates acetylcholine-induced invasion and migration by human gastric cancer cells. Oncotarget. 2016; 7:18085-94. https://doi.org/10.18632/oncotarget.7634. [PubMed] 
25. Lin A, Zhang X, Zhang R, He X, Zhang J, Yan W. Prognostic and Risk Stratification Value of Lesion MACC1 Expression in Colorectal Cancer Patients. Front Oncol. 2019; 9:28. https://doi.org/10.3389/fonc.2019.00028. [PubMed]

26. Symonds L, Baker K, Redman M, Koch L, Carter K, Yu M, Wirtz R, Poulios C, Pentheroudakis GE, Papaxoinis G, Pectasides DG, Kalogeras KT, Fountzilas G, et al. MACC1 expression as a candidate prognostic biomarker in colorectal cancer patients receiving adjuvant oxaliplatinbased therapy. J Clin Oncol. 2019; 37:567-567. https://doi. org/10.1200/JCO.2019.37.4 suppl.567.

27. Güllü N, Kobelt D, Brim H, Timm L, Smith J, Shoraka HR, Soleimani A, Bisti S, Gondré-Lewis MC, Ashktorab H, Stein UD. Saffron restricts MACC1-dependent cell proliferation and motility of colorectal cancer cells, and alters the microbiome structure. Cancer Res. 2019. https:// doi.org/10.1158/1538-7445.SABCS18-1858.

28. Yin QQ, Xu LH, Zhang M, Xu C. Muscarinic acetylcholine receptor M1 mediates prostate cancer cell migration and invasion through hedgehog signaling. Asian J Androl. 2018; 20:608-614. https://doi.org/10.4103/aja.aja_55_18.

29. Skoda AM, Simovic D, Karin V, Kardum V, Vranic S, Serman L. The role of the Hedgehog signaling pathway in cancer: A comprehensive review. Bosn J Basic Med Sci. 2018; 18:8-20. https://doi.org/10.17305/bjbms.2018.2756. [PubMed]

30. Grund-Gröschke S, Stockmaier G, Aberger F. Hedgehog/GLI signaling in tumor immunity - new therapeutic opportunities and clinical implications. Cell Commun Signal. 2019; 17:172. https://doi.org/10.1186/s12964-019-0459-7. [PubMed]

31. Gupta S, Takebe N, Lorusso P. Targeting the Hedgehog pathway in cancer. Therapeutic advances in medical oncology. Ther Adv Med Oncol. 2010; 2:237-250. https:// doi.org/10.1177/1758834010366430. [PubMed]

32. Zhang C, Yu P, Zhu L, Zhao Q, Lu X, Bo S. Blockade of $\alpha 7$ nicotinic acetylcholine receptors inhibit nicotine-induced tumor growth and vimentin expression in non-small cell lung cancer through MEK/ERK signaling way. Oncol Rep. 2017; 38:3309-18. https://doi.org/10.3892/or.2017.6014. [PubMed]

33. Nishioka T, Tada H, Ibaragi S, Chen C, Sasano T. Nicotine exposure induces the proliferation of oral cancer cells through the $\alpha 7$ subunit of the nicotinic acetylcholine receptor. Biochem Biophys Res Commun. 2019; 509:51420. https://doi.org/10.1016/j.bbrc.2018.12.154. [PubMed]

34. Chang J, Tang N, Fang Q, Zhu K, Liu L, Xiong X, Zhu Z, Zhang B, Zhang M, Tao J. Inhibition of COX-2 and 5 -LOX regulates the progression of colorectal cancer by promoting PTEN and suppressing PI3K/AKT pathway. Biochem Biophys Res Commun. 2019; 517:1-7. https:// doi.org/10.1016/j.bbrc.2018.01.061. [PubMed]

35. Goradel N, Najafi M, Salehi E, Farhood B, Mortezaee K. Cyclooxygenase-2 in cancer: A review. J Cell Physiol. 2019; 234:5683-99. https://doi.org/10.1002/jcp.27411. [PubMed]
36. Sheng J, Sun H, Yu FB, Li B, Zhang Y, Zhu YT. The Role of Cyclooxygenase-2 in Colorectal Cancer. Int J Med Sci. 2020; 17:1095-1101. https://doi.org/10.7150/ijms.44439. [PubMed]

37. Karpisheh V, Nikkhoo A, Hojjat-Farsangi M, Namdar A, Azizi G, Ghalamfarsa G, Sabz G, Yousefi M, Yousefi B, Jadidi-Niaragh F. Prostaglandin E2 as a potent therapeutic target for treatment of colon cancer. Prostaglandins Other Lipid Mediat. 2019; 144:106338. https://doi.org/10.1016/j. prostaglandins.2019.106338. [PubMed]

38. Ye Y, Wang X, Jeschke U, Schönfeldt V. COX-2-PGE2-EPs in gynecological cancers. Arch Gynecol Obstet. 2020; 301:1365-75. https://doi.org/10.1007/s00404-020-055596. [PubMed]

39. Mitschke J, Burk UC, Reinheckel T. The role of proteases in epithelial-to-mesenchymal cell transitions in cancer. Cancer Metastasis Rev. 2019; 38:431-44. https://doi.org/10.1007/ s10555-019-09808-2. [PubMed]

40. Agraval H, Yadav U. MMP-2 and MMP-9 mediate cigarette smoke extract-induced epithelial-mesenchymal transition in airway epithelial cells via EGFR/Akt/GSK3// $\beta$-catenin pathway: Amelioration by fisetin. Chem Biol Interact. 2019; 314:108846. https://doi.org/10.1016/j.cbi.2019.108846. [ [PubMed]

41. Xi Y, Zhang Y, Zhu S, Luo Y, Xu P, Huang Z. PPARMediated Toxicology and Applied Pharmacology. Cells. 2020; 9:352. https://doi.org/10.3390/cells9020352. [PubMed]

42. Wang H, Yang Y, Luo Q, Liu M, Luo C, Dong J, Guo J, Ye C. The PPAR signaling pathway as a potential biomarker for the diagnosis of breast cancer. Int J Clin Exp Med. 2019; 12:7327-36.

43. Seiri P, Abi A, Soukhtanloo M. PPAR- $\gamma$ : Its ligand and its regulation by microRNAs. J Cell Biochem. 2019; 120:10893908. https://doi.org/10.1002/jcb.28419. [PubMed]

44. Hojka A, Rapak A. [Peroxisome proliferator-activated receptors (PPAR). Antiproliferative properties]. [Article in Polish] Postepy Hig Med Dosw. 2011; 65:404-13. https://doi. org/10.5604/17322693.949463. [PubMed]

45. Khatol P, Saraf S, Jain A. Peroxisome Proliferated Activated Receptors (PPARs): Opportunities and Challenges for Ocular Therapy. Crit Rev Ther Drug Carrier Syst. 2018; 35:65-97. [PubMed]

46. Kotlinowski J, Jozkowicz A. PPAR Gamma and Angiogenesis: Endothelial Cells Perspective. J Diabetes Res. 2016; 2016:8492353. https://doi.org/10.1155/2016/8492353. [PubMed]

47. Hsu HT, Sung MT, Lee CC, Kuo YJ, Chi CW, Lee HC, Hsia CY. Peroxisome Proliferator-Activated Receptor Expression Is Inversely Associated with Macroscopic Vascular Invasion in Human Hepatocellular Carcinoma. Int J Mol Sci. 2016; 17:1226. https://doi.org/10.3390/ijms17081226. [PubMed]

48. Mello T, Materozzi M, Galli A. PPARs and Mitochondrial Metabolism: From NAFLD to HCC. PPAR Res. 2016; 2016:7403230. $\quad$ https://doi.org/10.1155/2016/7403230. [PubMed] 
49. Wu K, Yang Y, Liu D, Qi Y, Zhang C, Zhao J, Zhao S. Activation of PPAR $\gamma$ suppresses proliferation and induces apoptosis of esophageal cancer cells by inhibiting TLR4dependent MAPK pathway. Oncotarget. 2016; 7:44572-82. https://doi.org/10.18632/oncotarget.10067. [PubMed]

50. Velmurugan BK, Yang HH, Sung PJ, Weng CF. Excavatolide B Inhibits Nonsmall Cell Lung Cancer Proliferation by Altering Peroxisome Proliferator Activated Receptor Gamma Expression and PTEN/AKT/NF-Kb Expression. Environ Toxicol. 2017; 32:290-301. https:// doi.org/10.1002/tox.22235. [PubMed]

51. Ravi Kiran Ammu V, Garikapati K, Krishnamurthy P, Chintamaneni P, Pindiprolu S. Possible role of PPAR- $\gamma$ and COX-2 receptor modulators in the treatment of Non-Small Cell lung carcinoma. Med Hypotheses. 2019; 124:98-100. https://doi.org/10.1016/j.mehy.2019.02.024. [PubMed]

52. Ekambaram P, Lambiv W, Cazzolli R, Ashton A, Honn K. The thromboxane synthase and receptor signaling pathway in cancer: an emerging paradigm in cancer progression and metastasis. Cancer Metastasis Rev. 2011; 30:397-408. https://doi.org/10.1007/s10555-011-9297-9. [PubMed]

53. Huang R, Li S, Guo Z, Huang Y, Zhang X, Li MY, Chen GG, Zeng XT. Thromboxane A2 exerts promoting effects on cell proliferation through mediating cyclooxygenase-2 signal in lung adenocarcinoma cells. J Cancer Res Clin Oncol. 2014; 140:375-86. https://doi.org/10.1007/s00432013-1573-3. [PubMed]

54. Purvis G, Collino M, Tavio H, Chiazza F, O'Riodan C, Zeboudj L, Guisot N, Bunyard P, Greaves DR, Thiemermann C. Inhibition of Bruton's tyrosine kinase reduces NF-kB and NLRP3 inflammasome activity preventing insulin resistance and microvascular disease. bioRxiv. https://doi.org/10.1101/745943.

55. Burger J. Bruton Tyrosine Kinase Inhibitors Present and Future. Cancer J. 2019; 25:386-93. [PubMed]

56. Chu Y, Cairo M, Beishuizen A. Resistance to Bruton's Tyrosine Kinase Signaling Pathway Targeted Therapies. Springer Cham; 2019. pp. 111-53. https://doi. org/10.1007/978-3-030-24424-8_6.

57. Daniel S, Seo Y, Pillarisetty V. The CXCL12-CXCR4/ CXCR7 axis as a mechanism of immune resistance in gastrointestinal malignancies. Semin Cancer Biol. 2019;

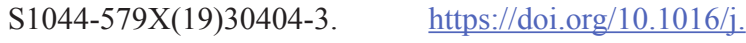
semcancer.2019.12.007. [PubMed]

58. Yu X, Wang D, Wang X, Sun S, Zhang Y, Wang S, Miao $\mathrm{R}, \mathrm{Xu}$ X, Qu X. CXCL12/CXCR4 promotes inflammationdriven colorectal cancer progression through activation of RhoA signaling by sponging miR-133a-3p. J Exp Clin Cancer Res. 2019; 38:32. https://doi.org/10.1186/s13046018-1014-x. [PubMed]

59. Nguyen KT, Druhan LJ, Avalos BR, Zhai L, Rauova L, Nesmelova IV, Dréau D, Dréau D. CXCL12-CXCL4 heterodimerization prevents CXCL12-driven breast cancer cell migration. Cell Signal. 2020; 66:109488. https://doi. org/10.1016/j.cellsig.2019.109488. [PubMed]
60. Molina-Cerrillo J, Alonso-Gordoa T, Gajate P, Grande E. Bruton's tyrosine kinase (Btk) as a promising target in solid tumors. Cancer Treat Rev. 2017; 58:41-50. https://doi. org/10.1016/j.ctrv.2017.06.001. [PubMed]

61. Ku CY, Liu YH, Lin HY, Lu SC, Lin JY. Liver fatty acid-binding protein (L-FABP) promotes cellular angiogenesis and migration in hepatocellular carcinoma. Oncotarget. 2016; 7:18229-46. https://doi.org/10.18632/oncotarget.7571. [ubMed]

62. Gurung S, Chung K, Lee T. Emerging role of fatty acid binding proteins in cancer pathogenesis. Histol Histopathol. 2019; 34:1-12. [PubMed]

63. McKillop I, Girardi C, Thompson K. Role of fatty acid binding proteins (FABPs) in cancer development and progression. Cell Signal. 2019; 62:109336. https://doi. org/10.1016/i.cellsig.2019.06.001. [PubMed]

64. Amiri M, Yousefnia S, Forootan F, Peymani M, Ghaedi K, Esfahani M. Diverse roles of fatty acid binding proteins (FABPs) in development and pathogenesis of cancers. Gene. 2018; 676:171-83. https://doi.org/10.1016/j. gene.2018.07.035. [PubMed]

65. Ren H, Fang J, Ding X, Chen Q. Role and inhibition of Src signaling in the progression of liver cancer. Open Life Sci. 2016; 11:513-8. https://doi.org/10.1515/biol-2016-0067.

66. Laouirem S, Sannier A, Norkowski E, Cauchy F, Doblas S, Rautou PE, Albuquerque M, Garteiser P, Sognigbé L, Raffenne J, van Beers BE, Soubrane O, Bedossa P, et al. Endothelial fatty liver binding protein 4: a new targetable mediator in hepatocellular carcinoma related to metabolic syndrome. Oncogene. 2019; 38:3033-46. https://doi. org/10.1038/s41388-018-0597-1. [PubMed]

67. Song GX, Shen YH, Liu YQ, Sun W, Miao LP, Zhou LJ, Liu HL, Yang R, Kong XQ, Cao KJ, Qian LM, Sheng YH. Overexpression of FABP3 promotes apoptosis through inducing mitochondrial impairment in embryonic cancer cells. J Cell Biochem. 2012; 113:3701-8. https://doi. org/10.1002/jcb.24243. [PubMed]

68. Dean S, Rhodes A. Triple negative breast cancer: The role of metabolic pathways. Malays J Pathol. 2014; 36:155-62. [PubMed]

69. Zhong C, Zhang X, Ma N, Zhang E, Li J, Jiang Y, Gao YZ, Yuan YM, Lan SQ, Xie D, Cheng SQ. FABP4 suppresses proliferation and invasion of hepatocellular carcinoma cells and predicts a poor prognosis for hepatocellular carcinoma. Cancer Med. 2018; 7:2629-40. https://doi.org/10.1002/ cam4.1511. [PubMed]

70. Hashimotoa T, Kusakabe T, Sugino T, Fukuda T, Watanabe K, Sato Y, Nashimoto A, Honma K, Kimura H, Fujii H, Suzuki T. Expression of Heart-Type Fatty Acid-Binding Protein in Human Gastric Carcinoma and Its Association with Tumor Aggressiveness. Pathobiology. 2004; 71:26773. [PubMed]

71. Hashimoto T, Kusakabe T, Sugino T, Fukuda T, Watanabe K, Sato Y, Nashimoto A, Honma K, Kimura H, Fujii H, Suzuki T. Elevated expression of FABP3 and FABP4 
cooperatively correlates with poor prognosis in non-small cell lung cancer (NSCLC). Oncotarget. 2016; 7:46253-62. https://doi.org/10.18632/oncotarget.10086. [PubMed]

72. Levi L, Wang Z, Doud MK, Hazen SL, Noy N. Saturated fatty acids regulate retinoic acid signalling and suppress tumorigenesis by targeting fatty acid-binding protein 5 . Nat Commun. 2015; 6:8794. https://doi.org/10.1038/ncomms9794. [PubMed]

73. Marion-Letellier R, Savoye G, Ghosh S. Fatty acids, eicosanoids and PPAR gamma. Eur J Pharmacol. 2016; 785:44 49. https:// doi.org/10.1016/j.ejphar.2015.11.004. [PubMed]

74. Morgan E, Kannan-Thulasiraman P, Noy N. Involvement of Fatty Acid Binding Protein 5 and PPAR $\beta / \delta$ in Prostate Cancer Cell Growth. PPAR Res. 2010; 2010:234629. https://doi.org/10.1155/2010/234629. [PubMed]

75. Carbonetti G, Wilpshaar T, Kroonen J, Studholme K, Converso C, d'Oelsnitz S, Kaczocha M. FABP5 coordinates lipid signaling that promotes prostate cancer metastasis. Sci Rep. 2019; 9:18944. https://doi.org/10.1038/s41598-01955418-x. [PubMed]

76. Al-Jameel W, Gou X, Jin X, Zhang J, Wei Q, Ai J, Li H, Al-Bayati A, Platt-Higgins A, Pettitt A, Rudland PS, Ke Y. Inactivated FABP5 suppresses malignant progression of prostate cancer cells by inhibiting the activation of nuclear fatty acid receptor PPAR $\gamma$. Genes Cancer. 2019; 10:80-96. https://doi.org/10.18632/genesandcancer.192. [PubMed]

77. Naeem A, Abdulsamad S, Rudland P, Malki M, Ke Y. Fatty acid-binding protein 5 (FABP5)-related signal transduction pathway in castration-resistant prostate cancer cells: a potential therapeutic target. Precis Clin Med. 2019; 3:1926. https://doi.org/10.1093/pcmedi/pbz015.

78. Nitschke K, Erben P, Waldbillig F, Abdelhadi A, Weis CA, Gottschalt M, Wahby S, Nuhn P, Boutros M, Michel MS, von Hardenberg J, Worst TS. Clinical relevance of gene expression in localized and metastatic prostate cancer exemplified by FABP5. World J Urol. 2020; 38:637-45. https://doi.org/10.1007/s00345-019-02651-8. [PubMed]

79. Carbonetti G, Converso C, Clement T, Wang C, Trotman LC, Ojima I, Kaczocha M. Docetaxel/cabazitaxel and fatty acid binding protein 5 inhibitors produce synergistic inhibition of prostate cancer growth. The Prostate. 2020; 80:88-98. https://doi.org/10.1002/pros.23921. [PubMed]

80. Al-Jameel W. FABP5-Related Signalling Pathway used as Therapeutic Target for Castration-Resistance Prostate Cancer. $\mathrm{PhD}$ thesis, University of Liverpool. https:// livrepository.liverpool.ac.uk/3007987/.

81. Forootan F, Forootan S, Gou X, Yang J, Liu B, Chen D, Saad Al Fayi M, Al-Jameel W, Rudland FS, Hussain SA, Ke Y. Fatty Acid Activated PPAR $\gamma$ Promotes Tumorigenicity of Prostate Cancer Cells by Up Regulating VEGF via PPAR Responsive Elements of the Promoter. Oncotarget. 2016; 7:9322-39. https://doi.org/10.18632/oncotarget.6975. [PubMed]

82. Kawaguchi K, Senga S, Kubota C, Kawamura Y, Ke Y, Fujii H. High expression of Fatty Acid-Binding Protein 5 promotes cell growth and metastatic potential of colorectal cancer cells. FEBS Open Bio. 2016; 6:190-9. https://doi. org/10.1002/2211-5463.12031. [PubMed]

83. Pagano E, Borrelli F, Orlando P, Romano B, Monti M, Morbidelli L, Aviello G, Imperatore R, Capasso R, Piscitelli F, Buono L, Di Marzo V, Izzo AA. Pharmacological inhibition of MAGL attenuates experimental colon carcinogenesis. Pharmacol Res. 2017; 119:227-236. https:// doi.org/10.1016/j.phrs.2017.02.002. [PubMed]

84. Ramos-Bueno R, González-Fernández M, Guil-Guerrero J. Various acylglycerols from common oils exert different antitumor activities on colorectal cancer cells. Nutr Cancer. 2016; 68:518 29. http://doi.org/10.1080/01635581.2016.1152382. [PubMed]

85. Zhang Y, Zhao X, Deng L, Li X, Wang G, Li Y, Chen M. High expression of FABP4 and FABP6 in patients with colorectal cancer. World J Surg Oncol. 2019; 17:171. https://doi.org/10.1186/s12957-019-1714-5. [PubMed]

86. Yang W, Ma J, Zhou W, Li Z, Zhou X, Cao B, Zhang Y, Liu J, Yang Z, Zhang H, Zhao Q, Hong L, Fan D. Identification of hub genes and outcome in colon cancer based on bioinformatics analysis. Cancer Manag Res. 2018; 11:323338. https://doi.org/10.2147/CMAR.S173240. [PubMed]

87. Zhao ZW, Fan XX, Yang LL, Song JJ, Fang SJ, Tu JF, Chen MJ, Zheng LY, Wu FZ, Zhang DK, Ying XH, Ji JS. The identification of a common different gene expression signature in patients with colorectal cancer. Math Biosci Eng. 2019; 16:2942-58. [PubMed]

88. Unno M. Bile Acid and Colorectal Cancer. In: Tazuma S, Takikawa H, editors. Bile Acids in Gastroenterology. Tokyo: Springer; 2017. pp. 185-92. https://doi.org/10.1007/978-4431-56062-3 14.

89. Ocvirk S, O'Keefe S. Influence of Bile Acids on Colorectal Cancer Risk: Potential Mechanisms Mediated by Diet-Gut Microbiota Interactions. Curr Nutr Rep. 2017; 6:315-22. https://doi.org/10.1007/s13668-017-0219-5. [PubMed]

90. Ajouz H, Mukherji D, Shamseddine A. Secondary bile acids: an underrecognized cause of colon cancer. World J Surg Oncol. 2014; 12:164. https://doi.org/10.1186/14777819-12-164. [PubMed]

91. Nguyen TT, Ung TT, Kim NH, Jung YD. Role of bile acids in colon carcinogenesis. World J Clin Cases. 2018; 6:577588. https://doi.org/10.12998/wjcc.v6.i13.577. [PubMed]

92. Ticho A, Malhotra P, Dudeja P, Gill R, Alrefai W. Bile acid receptors and gastrointestinal functions. Liver Res. 2019; 3:3139. https://doi.org/10.1016/j.livres.2019.01.001. [PubMed]

93. Claudel T, Trauner M. Bile Acids as Signaling Molecules. The Liver Biology and Pathobiology. https://doi. org/10.1002/9781119436812.ch25.

94. Kosicka E, Lesicki A, Pieńkowska J. Molluscan aquaporins: an overview, with some notes on their role in the entry into aestivation in gastropods. Molluscan Res. 2020; 40:101-11. https://doi.org/10.1080/13235818.2020.1716442.

95. Staunton C, Vasilaki A, McArdle A, Jackson M, BarrettJolley R. Aquaporin transport of hydrogen peroxide in skeletal muscle. FASEB J. 2020; 34:1. 
96. Bestetti S, Galli M, Sorrentino I, Pinton P, Rimessi A, Sitia R, Medraño-Fernandez I. Human aquaporin-11 guarantees efficient transport of $\mathrm{H} 2 \mathrm{O} 2$ across the endoplasmic reticulum membrane. Redox Biol. 2020; 28:101326. https:// doi.org/10.1016/j.redox.2019.101326. [PubMed]

97. Nagaraju GP, Basha R, Rajitha B, Alese OB, Alam A, Pattnaik S, El-Rayes B. Aquaporins: Their role in gastrointestinal malignancies. Cancer Lett. 2016; 373:1218. https://doi.org/10.1016/j.canlet.2016.01.003. [PubMed]

98. Kasa P, Farran B, Prasad G, Nagaraju G. Aquaporins in female specific cancers. Gene. 2019; 700:60-4. https://doi. org/10.1016/j.gene.2019.03.032. [PubMed]

99. Maugeri R, Schiera G, Di Liegro CM, Fricano A, Iacopino DG, Di Liegro I. Aquaporins and Bain Tumors. Int J Mol Sci. 2016; 17:1029. https://doi.org/10.3390/ijms17071029. [PubMed]

100. Elkhider A, Wang B, Ouyang X, Al Azab M, Walana W, Sun X, Li H, Tang Y, Wei J, Li X. Aquaporin 5 promotes tumor migration and angiogenesis in non-small cell lung cancer cell line H1299. Oncol Lett. 2020; 19:1665-72. https://doi. org/10.3892/ol.2020.11251. [ubMed]

101. Arsenijevic T, Perret J, Van Laethem JL, Delporte C. Aquaporins Involvement in Pancreas Physiology and in Pancreatic Diseases. Int J Mol Sci. 2019; 20:5052. https:// doi.org/10.3390/ijms20205052. [PubMed]

102. Ribatti D, Ranieri G, Annese T, Nico B. Aquaporins in cancer. Biochim Biophys Acta. 2014; 1840:1550-1553. https://doi.org/10.1016/j.bbagen.2013.09.025. [PubMed]

103. Papadopoulos MC, Saadoun S. Key roles of aquaporins in tumor biology. Biochim Biophys Acta. 2015; 1848:2576-83. https://doi.org/10.1016/j.bbamem.2014.09.001. [PubMed]

104. Maltaneri R, Schiappacasse A, Chamorro M, Nesse A, Vittori D. Aquaporin-1 plays a key role in erythropoietininduced endothelial cell migration. Biochim Biophys Acta Mol Cell Res. 2020; 1867:118569. https://doi.org/10.1016/j. bbamcr.2019.118569. [PubMed]

105. Innocenti M. New insights into the formation and the function of lamellipodia and ruffles in mesenchymal cell migration. Cell Adhes Migr. 2018; 12:401-416. https://doi. org/10.1080/19336918.2018.1448352. [PubMed]

106. Hui TH, Cho WC, Fong HW, Yu M, Kwan KW, Ngan KC, Wong KH, Tan Y, Yao S, Jiang H, Gu Z, Lin Y. An electro-osmotic microfluidic system to characterize cancer cell migration under confinement. J R Soc Interface. 2019; 16:20190062. $\quad$ https://doi.org/10.1098/rsif.2019.0062. [PubMed]

107. Mierke CT. The matrix environmental and cell mechanical properties regulate cell migration and contribute to the invasive phenotype of cancer cells. Rep Prog Phys. 2019; 82:064602. https://doi.org/10.1088/1361-6633/ab1628. [PubMed]

108. Moosavi MS, Elham Y. Aquaporins 1, 3 and 5 in Different Tumors, their Expression, Prognosis Value and Role as New Therapeutic Targets. Pathol Oncol Res. 2020; 26:615-625. https://doi.org/10.1007/s12253-019-00646-9. [PubMed]
109. Yoshino D, Funamoto K, Sato K, Kenry, Sato M, Lim CT. Hydrostatic pressure promotes endothelial tube formation through aquaporin 1 and Ras-ERK signaling. Commun Biol. 2020; 3:152. https://doi.org/10.1038/s42003-0200881-9. [PubMed]

110. Jensen HH, Login FH, Koffman JS, Kwon TH, Nejsum LN. The role of aquaporin- 5 in cancer cell migration: A potential active participant. Int J Biochem Cell Biol. 2016; 79:271-6. https://doi.org/10.1016/j.biocel.2016.09.005. [PubMed]

111. Li Z, Li B, Zhang L, Chen L, Sun G, Zhang Q, Wang J, Zhi X, Wang L, Xu Z, Xu H. The proliferation impairment induced by AQP3 deficiency is the result of glycerol uptake and metabolism inhibition in gastric cancer cells. Tumour Biol. 2016; 37:9169-79. https://doi.org/10.1007/s13277015-4753-8. [PubMed]

112. Aikman B, de Almeida A, Meier-Menches SM, Casini A. Aquaporins in cancer development: opportunities for bioinorganic chemistry to contribute novel chemical probes and therapeutic agents. Metallomics. 2018; 10:696-712. https://doi.org/10.1039/C8MT00072G. [PubMed]

113. Jackson MJ, Stretton C, McArdle A. Hydrogen peroxide as a signal for skeletal muscle adaptations to exercise: What do concentrations tell us about potential mechanisms? Redox Biol. 2020; 35:101484. https://doi.org/10.1016/j. redox.2020.101484. [PubMed]

114. Zhang Y, Park J, Han SJ, Lim Y, Park I, Kim JS, Woo HA, Lee SR. Peroxiredoxin III Protects Tumor Suppressor PTEN from Oxidation by 15-Hydroperoxy-eicosatetraenoic Acid. Oxid Med Cell Longev. 2019; 2019:2828493. https:// doi.org/10.1155/2019/2828493. [PubMed]

115. Hara-Chikuma M, Watanabe S, Satooka H. Involvement of aquaporin-3 in epidermal growth factor receptor signaling via hydrogen peroxide transport in cancer cells. Biochem Biophys Res Commun. 2016; 471:603-9. https://doi. org/10.1016/j.bbrc.2016.02.010. [PubMed]

116. Satooka H, Hara-Chikuma M. Aquaporin-3 Controls Breast Cancer Cell Migration by Regulating Hydrogen Peroxide Transport and Its Downstream Cell Signaling. Mol Cell Biol. 2016; 36:1206-18. https://doi.org/10.1128/ MCB.00971-15. [PubMed]

117. Cao C, Sun Y, Healey S, Bi Z, Hu G, Wan S, Kouttab N, Chu W, Wan Y. EGFR-mediated expression of aquaporin-3 is involved in human skin fibroblast migration. Biochem J. 2006; 400:225-34. https://doi.org/10.1042/BJ20060816. [PubMed]

118. Zhou Y, Wang L, Wang C, Wu Y, Chen D, Lee TH. Potential implications of hydrogen peroxide in the pathogenesis and therapeutic strategies of gliomas. Arch Pharm Res. 2020; 43:187-203. https://doi.org/10.1007/s12272-020-01205-6. [PubMed]

119. Balogh E, Tóth A, Méhes G, Trencsényi G, Paragh G, Jeney V. Hypoxia Triggers Osteochondrogenic Differentiation of Vascular Smooth Muscle Cells in an HIF-1 (HypoxiaInducible Factor 1)-Dependent and Reactive Oxygen Species-Dependent Manner. Arterioscler Thromb 
Vasc Biol. 2019; 39:1088-99. https://doi.org/10.1161/ ATVBAHA.119.312509. [PubMed]

120. Kong H, Chandela NS. Reactive oxygen species and cancer. Oxidative Stress; 2020. pp. 619-37. https://doi.org/10.1016/ B978-0-12-818606-0.00030-4.

121. Huang W, Li BR, Feng H. PLAG1 silencing promotes cell chemosensitivity in ovarian cancer via the IGF2 signaling pathway. Int J Mol Med. 2020; 45:703-14. https://doi. org/10.3892/ijmm.2020.4459. [PubMed]

122. Simpson A, Petnga W, Macaulay VM, Weyer-Czernilofsky U, Bogenrieder T. Insulin-Like Growth Factor (IGF) Pathway Targeting in Cancer: Role of the IGF Axis and Opportunities for Future Combination Studies. Target Oncol. 2017; 12:571-97. https://doi.org/10.1007/s11523017-0514-5. [PubMed]

123. Brahmkhatri VP, Prasanna C, Atreya HS. Insulin-like growth factor system in cancer: novel targeted therapies. BioMed Res Int. 2015; 2015:538019. [PubMed]

124. Zhang Q, Yang J, Bai J, Ren J. Reverse of non-small cell lung cancer drug resistance induced by cancer-associated fibroblasts via a paracrine pathway. Cancer Sci. 2018; 109:944-955. https://doi.org/10.1111/cas.13520. [PubMed]

125. Kasprzak A, Adamek A. Insulin-Like Growth Factor 2 (IGF2) Signaling in Colorectal Cancer-From Basic Research to Potential Clinical Applications. Int J Mol Sci. 2019; 20:4915. https://doi.org/10.3390/ijms20194915. [PubMed]

126. Vella V, Nicolosi ML, Cantafio P, Massimino M, Lappano R, Vigneri P, Ciuni R, Gangemi P, Morrione A, Malaguarnera R, Belfiore A. DDR1 regulates thyroid cancer cell differentiation via IGF-2/IR-A autocrine signaling loop. Endocr Relat Cancer. 2019; 26:197-214. https://doi. org/10.1530/ERC-18-0310. [PubMed]

127. Onyema ME, Drakou E, Giovos G, Leca BM, Kosmas C, Ganguly R, Murthy M, Grossman AB, Randeva HS, Dimitriadis GK. Paraneoplastic hypoglycaemia secondary to IGF-2 secretion from a metastatic gastrointestinal stromal tumour. Endocrine and Metabolic Science. 2020; 1:100047. https://doi.org/10.1016/j.endmts.2020.100047.

128. Ekyalongo RC, Yee D. Revisiting the IGF-1R as a breast cancer target. Version 2. NPJ Precision Oncology. 2017; 1:14. https://doi.org/10.1038/s41698-017-0017-y. [PubMed]

129. Scalia P, Pandini G, Carnevale V, Giordano A, Williams SJ. Identification of a novel EphB4 phosphodegron regulated by the autocrine IGFII/IRA axis in malignant mesothelioma. Oncogene. 2019; 38:5987-6001. https://doi.org/10.1038/ s41388-019-0854-y. [PubMed]

130. Scalia P, Giordano A, Williams SJ. The IGF-II-Insulin Receptor Isoform-A Autocrine Signal in Cancer: Actionable Perspectives. Cancers (Basel). 2020; 12:366. https://doi. org/10.3390/cancers12020366. [PubMed]

131. Natsuizaka M, Kinugasa H, Kagawa S, Whelan KA, Naganuma S, Subramanian H, Chang S, Nakagawa KJ, Rustgi NL, Kita Y, Natsugoe S, Basu D, Gimotty PA, et al.
IGFBP3 promotes esophageal cancer growth by suppressing oxidative stress in hypoxic tumor microenvironment. Am J Cancer Res. 2014; 4:29-41. [PubMed]

132. Adachi Y, Nojima M, Mori M, Yamashita K, Yamano HO, Nakase H, Endo T, Wakai K, Sakata K, Tamakoshi A. Insulin-like growth factor-1, IGF binding protein-3, and the risk of esophageal cancer in a nested case-control study. World J Gastroenterol. 2017; 23:3488-95. https://doi. org/10.3748/wjg.v23.i19.3488. [PubMed]

133. Mancarella C, Scotlandi K. IGF2BP3 From Physiology to Cancer: Novel Discoveries, Unsolved Issues, and Future Perspectives. Front Cell Dev Biol. 2020; 7:363. https://doi. org/10.3389/fcell.2019.00363. [PubMed]

134. Xu X, Yu Y, Zong K, Lv P, Gu Y. Up-regulation of IGF2BP2 by multiple mechanisms in pancreatic cancer promotes cancer proliferation by activating the $\mathrm{PI} 3 \mathrm{~K} /$ Akt signaling pathway. J Exp Clin Cancer Res. 2019; 38:497. https://doi. org/10.1186/s13046-019-1470-y. [PubMed]

135. Dahlem C, Barghash A, Puchas P, Haybaeck J, Kessler SM. The Insulin-Like Growth Factor 2 mRNA Binding Protein IMP2/IGF2BP2 is Overexpressed and Correlates with Poor Survival in Pancreatic Cancer. Int J Mol Sci. 2019; 20:3204. https://doi.org/10.3390/ijms20133204. [PubMed]

136. Liu S, Zhan Y, Luo J, Feng J, Lu J, Zheng H, Wen Q, Fan S. Roles of exosomes in the carcinogenesis and clinical therapy of nonsmall cell lung cancer. Biomed Pharmacother. 2019; 111:338346. https://doi.org/10.1016/j.biopha.2018.12.088. [PubMed]

137. Bayraktar R, Bertilaccio MTS, Calin GA. The Interaction Between Two Worlds: MicroRNAs and Toll-Like Receptors. Front Immunol. 2019; 10:1053. https://doi. org/10.3389/fimmu.2019.01053. [PubMed]

138. Liang H, Kidder K, Liu Y. Extracellular microRNAs initiate immunostimulation via activating toll-like receptor signaling pathways. ExRNA. 2019; 1:9. https://doi. org/10.1186/s41544-019-0009-x.

139. Liang W, Ferrara N. The Complex Role of Neutrophils in Tumor Angiogenesis and Metastasis. Cancer Immunol Res. 2016; 4:83-91. https://doi.org/10.1158/2326-6066.CIR-150313. [PubMed]

140. Tohme S, Yazdani H, Simmons R, Tsung A, Bartlett D. Neutrophil extracellular traps regulate mitochondrial quality control in cancer cells to promote tumor growth. AACR Annual Meeting. 2019. https://doi.org/10.1158/1538-7445. AM2019-2818.

141. Egeblad M. Neutrophil extracellular traps promote breast cancer metastasis [abstract] In: Proceedings of the Breast Cancer Symposium. San Antonio, TX. Philadelphia (PA): AACR; Cancer Res. 2019; 79:BS1-2. https://doi. org/10.1158/1538-7445.SABCS18-BS1-2.

142. Granot Z. Neutrophils as a Therapeutic Target in Cancer. Front Immunol. 2019; 10:1710. https://doi.org/10.3389/ fimmu.2019.01710. [ [PubMed]

143. Mollinedo F. Neutrophil Degranulation, Plasticity, and Cancer Metastasis. Trends Immunol. 2019; 40:228-42. https://doi.org/10.1016/j.it.2019.01.006. [ [PubMed] 
144. Cools-Lartigue J, Spicer J, McDonald B, Gowing S, Chow S, Giannias B, Bourdeau F, Kubes P, Ferri L. Neutrophil extracellular traps sequester circulating tumor cells and promote metastasis. J Clin Invest. 2013; 123:3446-58. https://doi.org/10.1172/JCI67484. [PubMed]

145. Iriondo O, Yu M. Unexpected Friendship: Neutrophils Help Tumor Cells En Route to Metastasis. Dev Cell. 2019; 49:308-10. https://doi.org/10.1016/j.devcel.2019.04.021. [PubMed]

146. Han Y, Ren J, Bai Y, Pei X, Han Y. Exosomes from hypoxia-treated human adipose-derived mesenchymal stem cells enhance angiogenesis through VEGF/VEGF-R. Int J Biochem Cell Biol. 2019; 109:59-68. https://doi. org/10.1016/j.biocel.2019.01.017. [PubMed]

147. Zeng Y, Yao X, Liu X, He X, Li L, Liu X, Yan Z, Wu J, $\mathrm{Fu}$ BM. Anti-angiogenesis triggers exosomes release from endothelial cells to promote tumor vasculogenesis. J Extracell Vesicles. 2019; 8:1629865. https://doi.org/10.108 0/20013078.2019.1629865. [PubMed]

148. Sexton RE, Mpilla G, Kim S, Philip PA, Azmi AS. Ras and exosome signaling. Semin Cancer Biol. 2019; 54:131-7. https://doi.org/10.1016/j.semcancer.2019.02.004. [PubMed]

149. Yaghoubi S, Najminejad H, Dabaghian M, Karimi MH, Abdollahpour-Alitappeh M, Rad F, Mahi-Birjand M, Mohammadi S, Mohseni F, Sobhani Lari M, Teymouri GH, Rigi Yousofabadi E, Salmani A, Bagheri N. How hypoxia regulate exosomes in ischemic diseases and cancer microenvironment? IUBMB Life. 2020; 72:1286-1305. https://doi.org/10.1002/iub.2275. [PubMed]

150. Xie JY, Wei JX, Lv LH, Han QF, Yang WB, Li GL, Wang PX, Wu SB, Duan JX, Zhuo WF, Liu PQ, Min J. Angiopoietin-2 induces angiogenesis via exosomes in human hepatocellular carcinoma. Cell Commun Signal. 2020; 18:46. https://doi.org/10.1186/s12964-020-00535-8. [PubMed]

151. Fan J, Xu G, Chang Z, Zhu L, Yao J. miR-210 transferred by lung cancer cell-derived exosomes may act as proangiogenic factor in cancer-associated fibroblasts by modulating JAK2/STAT3 pathway. Clin Sci (Lond). 2020; 134:807-25. https://doi.org/10.1042/CS20200039. [PubMed]

152. Wang X, Wang T, Chen C, Wu Z, Bai P, Li S, Chen B, Liu R, Zhang K, Li W, Chen Y, Xing J. Serum exosomal miR-210 as a potential biomarker for clear cell renal cell carcinoma. J Cell Biochem. 2018 Oct 10. https://doi. org/10.1002/jcb.27347. [PubMed] [Epub ahead of print]

153. Wang Z, Deng M, Liu Z, Wu S. Hypoxia-induced miR-210 promoter demethylation enhances proliferation, autophagy and angiogenesis of schwannoma cells. Oncol Rep. 2017; 37:3010-18. https://doi.org/10.3892/or.2017.5511. [PubMed]

154. Wang L, Song Y, Wang H, Liu K, Shao Z, Shang Z. MiR210-3p-EphrinA3-PI3K/AKT axis regulates the progression of oral cancer. J Cell Mol Med. 2020; 24:4011-22. https:// doi.org/10.1111/jcmm.15036. [PubMed]
155. Peters MMC, Sampaio-Pinto V, da Costa Martins PA. Noncoding RNAs in endothelial cell signalling and hypoxia during cardiac regeneration. Biochim Biophys Acta Mol Cell Res. 2020; 1867:118515. https://doi.org/10.1016/j. bbamcr.2019.07.010. [PubMed]

156. Song W, Yan D, Wei T, Liu Q, Zhou X, Liu J. Tumorderived extracellular vesicles in angiogenesis. Biomed Pharmacother. 2018; 102:1203-8. https://doi.org/10.1016/j. biopha.2018.03.148. [PubMed]

157. Sun JJ, Zhang XY, Qin XD, Zhang J, Wang MX, Yang JB. MiRNA-210 induces the apoptosis of neuronal cells of rats with cerebral ischemia through activating HIF-1 $\alpha$-VEGF pathway. Eur Rev Med Pharmacol Sci. 2019; 23:2548-54. https://doi.org/10.26355/eurrev_201903_17403. [PubMed]

158. Zhuang G, Wu X, Jiang Z, Kasman I, Yao J, Guan Y, Oeh J, Modrusan Z, Bais C, Sampath D, Ferrara N. Tumoursecreted miR-9 promotes endothelial cell migration and angiogenesis by activating the JAK-STAT pathway. EMBO J. 2012; 31:3513-23. https://doi.org/10.1038/ emboj.2012.183. [PubMed]

159. Mullany LE, Herrick JS, Sakoda LC, Samowitz W, Stevens JR, Wolff RK, Slattery ML. MicroRNA-messenger RNA interactions involving JAK-STAT signaling genes in colorectal cancer. Genes Cancer. 2018; 9:232-46. https:// doi.org/10.18632/genesandcancer.177. [PubMed]

160. Nowek K, Wiemer EAC, Jongen-Lavrencic M. The versatile nature of miR-9/9* in human cancer. Oncotarget. 2018; 9:20838-54. https://doi.org/10.18632/oncotarget.24889. [PubMed]

161. Chen Z, Han ZC. STAT3: a critical transcription activator in angiogenesis. Med Res Rev. 2008; 28:185-200. https://doi. org/10.1002/med.20101. [PubMed]

162. Takahashi RU, Prieto-Vila M, Kohama I, Ochiya T. Development of miRNA-based therapeutic approaches for cancer patients. Cancer Sci. 2019; 110:1140-47. https://doi. org/10.1111/cas.13965. [PubMed]

163. Bach DH, Hong JY, Park HJ, Lee SK. The role of exosomes and miRNAs in drug-resistance of cancer cells. Int J Cancer. 2017; 141:220-230. https://doi.org/10.1002/ijc.30669. [PubMed]

164. Zhou W, Fong MY, Min Y, Somlo G, Liu L, Palomares MR, Yu Y, Chow A, O'Connor ST, Chin AR, Yen Y, Wang Y, Marcusson EG, et al. Cancer-secreted miR-105 destroys vascular endothelial barriers to promote metastasis. Cancer Cell. 2014; 25:501-15. https://doi.org/10.1016/j. ccr.2014.03.007. [PubMed]

165. Hu C, Meiners S, Lukas C, Stathopoulos GT, Chen J. Role of exosomal microRNAs in lung cancer biology and clinical applications. Cell Prolif. 2020; 11:e12828. https:// doi.org/10.1111/cpr.12828. [PubMed]

166. Nan X, Wang J, Liu HN, Wong STC, Zhao H. EpithelialMesenchymal Plasticity in Organotropism Metastasis and Tumor Immune Escape. J Clin Med. 2019; 8:747. https:// doi.org/10.3390/jcm8050747. [PubMed] 
167. Liang Y, Yang C, Lin Y, Parviz Y, Sun K, Wang W, Ren M, Yan L. Matrix metalloproteinase 9 induces keratinocyte apoptosis through FasL/Fas pathway in diabetic wound. Apoptosis. 2019; 24:542-51. https://doi.org/10.1007/ s10495-019-01536-w. [ubMed]

168. Mondal S, Adhikari N, Banerjee S, Amin S, Jha T. Matrix metalloproteinase-9 (MMP-9) and its inhibitors in cancer: A minireview. Eur J Med Chem. 2020; 194:112260. https:// doi.org/10.1016/j.ejmech.2020.112260. [PubMed]

169. Mohan V, Das A, Sagi I. Emerging roles of ECM remodeling processes in cancer. Semin Cancer Biol. 2020; 62:192-200. https://doi.org/10.1016/j.semcancer.2019.09.004. [PubMed]

170. Feng W, Dean DC, Hornicek FJ, Shi H, Duan Z. Exosomes promote pre-metastatic niche formation in ovarian cancer. Mol Cancer. 2019; 18:124. https://doi.org/10.1186/s12943019-1049-4. [PubMed]

171. Meng W, Hao Y, He C, Li L, Zhu G. Exosome-orchestrated hypoxic tumor microenvironment. Mol Cancer. 2019; 18:57. https://doi.org/10.1186/s12943-019-0982-6. [PubMed]

172. Bland TB, Wu B. Repurposing antimuscarinics to treat lethal chemoresistant prostate and lung cancers. J Clin Oncol. 2020; 38:e15636-e15636.

173. Lin G, He Y, Han D, Shi D, Liu T, Gao Y, Guan W, Cheng G. Aclidinium Bromide holds promising inhibitory effects in A549 lung cancer cells potentials by regulating PI3K/AKT signaling pathway. J BUON. 2019; 24:560-565. [PubMed]

174. Witayateeraporn W, Arunrungvichian K, Pothongsrisit S, Doungchawee J, Vajragupta O, Pongrakhananon V. $\alpha 7-$ Nicotinic acetylcholine receptor antagonist QND7 suppresses non-small cell lung cancer cell proliferation and migration via inhibition of Akt/mTOR signaling. Biochem Biophys Res Commun. 2020; 521:977-983. https://doi. org/10.1016/j.bbrc.2019.11.018. [PubMed]

175. Löfling L, Sundström A, Kieler H, Bahmanyar S, Linder M. Exposure to antimuscarinic medications for treatment of overactive bladder and risk of lung cancer and colon cancer. Clin Epidemiol. 2019; 11:133-143. https://doi.org/10.2147/ CLEP.S186842. [PubMed]

176. Wang Z, Gao J, Ohno Y, Liu H, Xu C. Rosiglitazone ameliorates senescence and promotes apoptosis in ovarian cancer induced by olaparib. Cancer Chemother Pharmacol. 2020; 85:273-284. https://doi.org/10.1007/s00280-01904025-8. [PubMed]

177. Konger RL, Derr-Yellin E, Ermatov N, Ren L, Sahu RP. The PPAR $\gamma$ Agonist Rosiglitazone Suppresses Syngeneic Mouse SCC (Squamous Cell Carcinoma) Tumor Growth through an Immune-Mediated Mechanism. Molecules. 2019; 24:2192. https://doi.org/10.3390/molecules24112192. [PubMed]

178. Lau MF, Chua KH, Sabaratnam V, Kuppusamy UR. Rosiglitazone enhances the apoptotic effect of 5-fluorouracil in colorectal cancer cells with high-glucoseinduced glutathione. Sci Prog. 2020; 103:36850419886448. https://doi.org/10.1177/0036850419886448. [PubMed]
179. Saito M, Fujita Y, Kuribayashi N, Uchida D, Komiyama Y, Fukumoto C, Hasegawa T, Kawamata H. Troglitazone, a Selective Ligand for PPAR $\gamma$, Induces Cell-cycle Arrest in Human Oral SCC Cells. Anticancer Res. 2020; 40:12471254. https://doi.org/10.21873/anticanres.14066. [PubMed]

180. Dana N, Vaseghi G, Javanmard SH. PPAR $\gamma$ Agonist, Pioglitazone, Suppresses Melanoma Cancer in Mice by Inhibiting TLR4 Signaling. J Pharm Pharm Sci. 2019; 22:418-423. https://doi.org/10.18433/jpps30626. [PubMed]

181. Reichle A, Bross K, Vogt T, Bataille F, Wild P, Berand A, Krause SW, Andreesen R. Pioglitazone and rofecoxib combined with angiostatically scheduled trofosfamide in the treatment of far-advanced melanoma and soft tissue sarcoma. Cancer. 2004; 101:2247-56. https://doi. org/10.1002/cncr.20574. [PubMed]

182. Lavitrano M, Ianzano L, Bonomo S, Cialdella A, Cerrito MG, Pisano F, Missaglia C, Giovannoni R, Romano G, McLean CM, Voest EE, D'Amato F, Noli B, et al. BTK inhibitors synergise with 5-FU to treat drug-resistant TP53null colon cancers. J Pathol. 2020; 250:134-147. [PubMed]

183. Tankiewicz-Kwedlo A, Hermanowicz JM, Domaniewski T, Pawlak K, Rusak M, Pryczynicz A, Surazynski A, Kaminski T, Kazberuk A, Pawlak D. Simultaneous use of erythropoietin and LFM-A13 as a new therapeutic approach for colorectal cancer. Br J Pharmacol. 2018; 175:743-762. https://doi.org/10.1111/bph.14099. [PubMed]

184. Pal Singh S, Dammeijer F, Hendriks RW. Role of Bruton's tyrosine kinase in B cells and malignancies. Mol Cancer. 2018; 17:57. https://doi.org/10.1186/s12943-018-0779-Z. [PubMed]

185. Wang X, Wong J, Sevinsky CJ, Kokabee L, Khan F, Sun Y, Conklin DS. Bruton's Tyrosine Kinase Inhibitors Prevent Therapeutic Escape in Breast Cancer Cells. Mol Cancer Ther. 2016; 15:2198-208. https://doi.org/10.1158/15357163.MCT-15-0813. [PubMed]

186. Zucha MA, Wu AT, Lee WH, Wang LS, Lin WW, Yuan CC, Yeh CT. Bruton's tyrosine kinase (Btk) inhibitor ibrutinib suppresses stem-like traits in ovarian cancer. Oncotarget. 2015; 6:13255-68. https://doi.org/10.18632/ oncotarget.3658. [PubMed]

187. Guo W, Liu R, Bhardwaj G, Yang JC, Changou C, Ma AH, Mazloom A, Chintapalli S, Xiao K, Xiao W, Kumaresan P, Sanchez E, Yeh CT, et al. Targeting Btk/Etk of prostate cancer cells by a novel dual inhibitor. Cell Death Dis. 2014; 5:e1409. https://doi.org/10.1038/cddis.2014.343. [PubMed]

188. Li L, Peng Z, Hu Q, Xu L, Zou X, Yu Y, Huang D, Yi P. Berberine Suppressed Tumor Growth through Regulating Fatty Acid Metabolism and Triggering Cell Apoptosis via Targeting FABPs. Evid Based Complement Alternat Med. 2020; 2020:6195050. https://doi. org/10.1155/2020/6195050. [PubMed]

189. Hsiao YH, Chen NC, Koh YC, Nagabhushanam K, Ho CT, Pan MH. Pterostilbene Inhibits Adipocyte ConditionedMedium-Induced Colorectal Cancer Cell Migration through 
Targeting FABP5-Related Signaling Pathway. J Agric Food Chem. 2019; 67:10321-10329. https://doi.org/10.1021/acs. jafc.9b03997. [PubMed]

190. Chow PH, Kourghi M, Pei JV, Nourmohammadi S, Yool AJ. Furan 5-Hydroxymethyl-Furfural and Structurally Related Compounds Block the Ion Conductance in Human Aquaporin-1 Channels and Slow Cancer Cell Migration and Invasion. Mol Pharmacol. 2020; 98:38-48. https://doi. org $/ 10.1124 / \mathrm{mol} .119 .119172$. [PubMed]

191. De Ieso ML, Pei JV, Nourmohammadi S, Smith E, Chow $\mathrm{PH}$, Kourghi M, Hardingham JE, Yool AJ. Combined pharmacological administration of AQP1 ion channel blocker AqB011 and water channel blocker Bacopaside II amplifies inhibition of colon cancer cell migration. Sci Rep. 2019; 9:12635. https://doi.org/10.1038/s41598-019-490459. [PubMed]

192. Wang W, Li Q, Yang T, Li D, Ding F, Sun H, Bai G. Anti-cancer effect of Aquaporin 5 silencing in colorectal cancer cells in association with inhibition of Wnt/ $\beta$-catenin pathway. Cytotechnology. 2018; 70:615-624. https://doi. org/10.1007/s10616-017-0147-7. [PubMed]

193. Peng R, Zhao GX, Li J, Zhang Y, Shen XZ, Wang JY, Sun JY. Auphen and dibutyryl cAMP suppress growth of hepatocellular carcinoma by regulating expression of aquaporins 3 and 9 in vivo. World J Gastroenterol. 2016; 22:3341-54. https://doi.org/10.3748/wig.v22.112.3341. [PubMed]

194. Weyer-Czernilofsky U, Hofmann MH, Friedbichler K, Baumgartinger R, Adam PJ, Solca F, Kraut N, Nguyen HM, Corey E, Liu G, Sprenger CC, Plymate SR, Bogenrieder T. Antitumor Activity of the IGF-1/IGF-2-Neutralizing Antibody Xentuzumab (BI 836845) in Combination with Enzalutamide in Prostate Cancer Models. Mol Cancer Ther. 2020; 19:1059-1069. https://doi.org/10.1158/1535-7163. MCT-19-0378. [PubMed]

195. Hussain SA, Maroto P, Climent MA, Bianchini D, Jones RH, Lin C, Wang S, Dean E, Crossley K, Schlieker L, Bogenrieder T, De Bono JS. Targeting IGF-1/2 with xentuzumab (Xe) plus enzalutamide (En) in metastatic castration-resistant prostate cancer (mCRPC) after progression on docetaxel chemotherapy (DCt) and abiraterone (Abi): Randomized phase II trial results. J Clin Oncol. 2019; 37:5030-5030.
196. Bastos N, Ruivo CF, da Silva S, Melo SA. Exosomes in cancer: Use them or target them? Semin Cell Dev Biol. 2018; 78:13-21. http://doi.org/10.1016/j. semcdb.2017.08.009. [PubMed]

197. David G, Zimmermann P. Heparanase Involvement in Exosome Formation. Adv Exp Med Biol. 2020; 1221:285-307. https://doi.org/10.1007/978-3-030-34521-1_10. [PubMed]

198. Sento S, Sasabe E, Yamamoto T. Application of a Persistent Heparin Treatment Inhibits the Malignant Potential of Oral Squamous Carcinoma Cells Induced by Tumor CellDerived Exosomes. PLoS One. 2016; 11:e0148454. https:// doi.org/10.1371/journal.pone.0148454. [PubMed]

199. Franzen CA, Blackwell RH, Todorovic V, Greco KA, Foreman KE, Flanigan RC, Kuo PC, Gupta GN. Urothelial cells undergo epithelial-to-mesenchymal transition after exposure to muscle invasive bladder cancer exosomes. Oncogenesis. 2015; 4:e163. https://doi.org/10.1038/ oncsis.2015.21. [PubMed]

200. Qin X, Wang J, Wang X, Liu F, Jiang B, Zhang Y. Targeting Rabs as a novel therapeutic strategy for cancer therapy. Drug Discov Today. 2017; 22:1139-1147. https://doi. org/10.1016/j.drudis.2017.03.012. [PubMed]

201. Datta A, Kim H, McGee L, Johnson AE, Talwar S, Marugan J, Southall N, Hu X, Lal M, Mondal D, Ferrer M, Abdel-Mageed AB. High-throughput screening identified selective inhibitors of exosome biogenesis and secretion: A drug repurposing strategy for advanced cancer. Sci Rep. 2018; 8:8161. https:// doi.org/10.1038/s41598-018-26411-7. [PubMed]

202. Patel V, Liaw B, Oh W. The role of ketoconazole in current prostate cancer care. Nat Rev Urol. 2018; 15:643-651. https://doi.org/10.1038/s41585-018-0077-y. [PubMed]

203. Gu L, Xu Y, Xu W, Li M, Su H, Li C, Liu Z. The exosome secretion inhibitor neticonazole suppresses intestinal dysbacteriosis-induced tumorigenesis of colorectal cancer. Invest New Drugs. 2020; 38:221-228. https://doi. org/10.1007/s10637-019-00759-7. [PubMed]

204. Fuerst M. Tipifarnib Induces Durable Responses in HRAS-Mutant Head and Neck Cancer. Oncology Times. 2019; 41:33. https://doi.org/10.1097/01. COT.0000618268.67077.2b. 